Research article

urn:1sid:zoobank.org:pub:38BD13D5-2FC1-4DCD-87B2-BDE60B6FA8E2

\title{
Red Sea Leucothoidae (Crustacea: Amphipoda) including new and re-described species
}

\author{
Kristine N. WHITE ${ }^{1, *} \&$ Traudl KRAPP-SCHICKEL ${ }^{2}$ \\ ${ }^{1}$ The University of Tampa, 401 W. Kennedy Blvd, Tampa, FL 33606, U.S.A. \\ ${ }^{2}$ Zoological Research Museum Alexander Koenig, Adenauerallee 160, D-53113 Bonn, Germany. \\ *Corresponding author: knwhite@ut.edu \\ ${ }^{2}$ Email: traudl.krapp@uni-bonn.de \\ ${ }^{1}$ urn:1sid:zoobank.org:author:1206DA5D-7756-4D17-92D2-890AE8A49F88 \\ ${ }^{2}$ urn:lsid:zoobank.org:author:E1B1DCCF-04CB-4B1A-A69B-A7C25EC95A38
}

\begin{abstract}
Examination of leucothoid amphipods of the Red Sea has revealed seven species not previously reported from this location. Leucothoe minoculis sp. nov., Leucothoe pansa sp. nov., Leucothoe reimeri sp. nov., and Paranamixis sommelieri sp. nov. are described and the range of Leucothoe predenticulata Ledoyer, 1978, L. acutilobata Ledoyer, 1978 and L. squalidens Ledoyer, 1978 is expanded to include the Red Sea. Clarification of reports of L. acanthopus Schellenberg, 1928 and L. bannwarthi (Schellenberg, 1928) is provided and Leucothoe alani sp. nov. is described from outside the Red Sea.
\end{abstract}

Keywords. Leucothoidae, Red Sea, Leucothoe, Paranamixis, new species.

White K.N. \& Krapp-Schickel T. 2017. Red Sea Leucothoidae (Crustacea: Amphipoda) including new and redescribed species. European Journal of Taxonomy 324: 1-40. https://doi.org/10.5852/ejt.2017.324

\section{Introduction}

Leucothoid amphipods are common peracarid crustaceans in surveys from all marine ecosystems from the intertidal to the abyssal zone, and are among the earliest amphipods described. Many of these early species descriptions lacked taxonomic detail and were often poorly illustrated, making subsequent identification difficult (Minelli 1993; Thomas 2015). Including the species described here, Leucothoidae currently comprise 185 species in five genera: Anamixis Stebbing, 1897 (23 spp.); Nepanamixis Thomas, 1997 (4 spp.); Paranamixis Schellenberg, 1938 (16 spp.); Leucothoe Leach, 1814 (140 spp.); and Paraleucothoe Stebbing, 1899 (2 spp.). Leucothoids are typically endocommensal associates of sessile invertebrates such as sponges, ascidians, or bivalve mollusks, and are often incidentally collected from coral rubble samples.

Thirty-one leucothoid species have been previously reported from the Indian Ocean (Table 1), with six of these species collected from the Red Sea (Leucothoe acanthopus Schellenberg, 1928; L. bannwarthi (Schellenberg, 1928); L. crassimana Kossmann, 1880; L. furina (Savigny, 1816); L. safiae Lyons \& Myers, 1991; and Paranamixis bocki Schellenberg, 1938). Leucothoe acanthopus was first described (poorly) from the Suez Canal (Schellenberg 1928) and reported from the Dahlak Archipelago in the 
Red Sea (Ruffo 1969). Leucothoe bannwarthi was described from the Suez Canal (Schellenberg 1928; Monod 1937) and later reported from the Red Sea (Barnard 1937; Ruffo 1969; Ledoyer 1967, 1979, 1986). Subsequent reports of L. bannwarthi from the Western Indian Ocean represent a different species and are here described as such. Leucothoe crassimana has been reported several times from the Red Sea (Kossmann 1880; Sowinsky 1897, 1898; Stebbing 1906). Leucothoe furina was described from the Suez Canal (Savigny 1816) as Lycesta furina, and later reported from the Red Sea (Walker 1909; Barnard 1937; Ruffo 1969). Leucothoe safiae was described from Safi in the Gulf of Aqaba (Lyons \& Myers 1991). Lastly, Paranamixis bocki was originally described from the Gilbert Islands (Schellenberg 1938) and later reported from the Red Sea (Ruffo 1969). Ruffo (1969) reported Anamixis cavatura Thomas, 1997 from the Red Sea as Leucothoides pottsi Shoemaker, 1933. However, a discussion of this species is not included here as it is unlikely that a species from the Caribbean Sea also inhabits the Red Sea. This material was most probably a leucomorph of a Paranamixis species.

Examination of material collected by Ulrich Schiecke and James Davis Reimer has revealed several more leucothoid amphipod species that have not been previously reported from the Red Sea. Three new species of Leucothoe and one new species of Paranamixis are here described from the Red Sea. Leucothoe acanthopus is re-described with designation of a neotype. A new locality is recorded for Leucothoe predenticulata, L. acutilobata and L. squalidens, all Ledoyer, 1978, and clarification of Leucothoe bannwarthi from specimens collected in the Red Sea is provided. A new species is described for material collected in the Fiji islands, which was originally assigned to L. bannwarthi.

\section{Material and methods}

A marine sponge containing specimens of Leucothoe reimeri sp. nov. was collected via SCUBA by James Davis Reimer from Shi'b Pelam, Jazirat Burcan, and dissected in the laboratory. Ulrich Schiecke collected sponges, algae and coral rubble throughout the Red Sea. Specimens were preserved in $99.5 \%$ $\mathrm{EtOH}$. Specimens used for morphological analyses were transferred to glycerin, dissected, mounted on slides, and illustrated using a drawing tube attached to a compound microscope. Pencil drawings were scanned and digitally inked in Adobe ${ }^{\circledR}$ Illustrator CC 2015 using a Wacom ${ }^{\circledR}$ Tablet, following the methods of Coleman (2003).

Material (type and additional material examined) is deposited at the Museum für Naturkunde of the Humboldt Universität, Berlin (Germany) with the prefix MNHB or ZMB, and at the Museo civico di Storia naturale, Verona (Italy) with the prefix MVRCr.

\section{Abbreviations}

Figure legends:

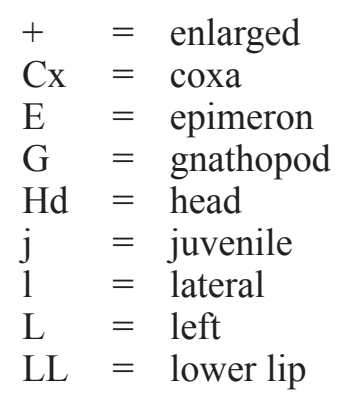

$\begin{aligned} \mathrm{m} & =\text { medial } \\ \mathrm{Md} & =\text { mandible } \\ \mathrm{Mx} & =\text { maxilla } \\ \mathrm{P} & =\text { pereopod } \\ \mathrm{R} & =\text { right } \\ \mathrm{T} & =\text { telson } \\ \mathrm{U} & =\text { uropod } \\ \mathrm{UL} & =\text { upper lip } \\ \mathrm{Xpd} & =\text { maxilliped }\end{aligned}$

Acronyms:
$\mathrm{AM} \quad=$ Australian Museum
MNHB or ZMB = Museum für Naturkunde der Humboldt Universität Berlin, Germany
$\mathrm{MVRCr}=$ Museo civico di Storia naturale, Verona, Italy 
Table 1 (continued on next page). Reports of Leucothoidae from the Indian Ocean until now (* denotes previous collections from the Red Sea; + denotes previously known species now reported from the Red Sea; \# denotes an identification we consider dubious).

\begin{tabular}{|c|c|c|c|c|c|}
\hline Species & Type locality & Additional reports & $\begin{array}{l}\text { Depth } \\
\text { (m) }\end{array}$ & Host & $\begin{array}{r}\text { Size } \\
(\mathrm{mm})\end{array}$ \\
\hline $\begin{array}{l}\text { Anamixis aldabra } \\
\text { Thomas, } 1997\end{array}$ & Seychelles & - & $2-3$ & coral rubble & 2.5 \\
\hline $\begin{array}{l}\text { Anamixis barnardi } \\
\text { Sasidharan, } 1983\end{array}$ & Gulf of Mannar & $\begin{array}{l}\text { Gulf of Mannar } \\
\text { (Thomas 1997) }\end{array}$ & littoral & sponges & $?$ \\
\hline $\begin{array}{l}\text { \#Anamixis cavatura } \\
\text { Thomas, } 1997\end{array}$ & Western Atlantic & $\begin{array}{c}\text { \#Madagascar (Ledoyer } \\
\text { 1967, 1978, 1979); \#Red Sea } \\
\text { (Ruffo, 1969) }\end{array}$ & $0-240$ & among coral & 2.4 \\
\hline $\begin{array}{l}\text { Anamixis mahe } \\
\text { Thomas, } 1997\end{array}$ & Seychelles & - & $0-1$ & coral rubble & 2.5 \\
\hline $\begin{array}{l}\text { *Leucothoe acanthopus } \\
\text { Schellenberg, } 1928\end{array}$ & Suez, Egypt & $\begin{array}{l}\text { Red Sea: Dahlak } \\
\text { (Ruffo 1969) }\end{array}$ & $?$ & $?$ & 3 \\
\hline $\begin{array}{l}\text { +Leucothoe acutilobata } \\
\text { Ledoyer, } 1978\end{array}$ & $\begin{array}{l}\text { Mauritius, } \\
\text { Madagascar }\end{array}$ & - & $0-25$ & among coral & 3 \\
\hline $\begin{array}{l}\text { Leucothoe angusticoxa } \\
\text { Ledoyer, } 1972\end{array}$ & $\begin{array}{l}\text { Tulear, } \\
\text { Madagascar }\end{array}$ & $\begin{array}{c}\text { Madagascar, Mauritius } \\
\text { (Ledoyer 1978, 1979, 1986) }\end{array}$ & $0-150$ & among coral & 4.8 \\
\hline $\begin{array}{l}\text { *Leucothoe bannwarthi } \\
\text { (Schellenberg, 1928) }\end{array}$ & Suez Canal & $\begin{array}{c}\text { Suez Canal (Monod 1937); } \\
\text { Red Sea (K.H. Barnard 1937; } \\
\text { Ruffo 1969); \#Madagascar } \\
\text { (Ledoyer 1967, 1972, 1978, } \\
\text { 1986) }\end{array}$ & $0-120$ & $\begin{array}{l}\text { coral, } \\
\text { seagrass, } \\
\text { sponge }\end{array}$ & 3.8 \\
\hline $\begin{array}{l}\text { *Leucothoe crassimana } \\
\text { Kossman, } 1880\end{array}$ & Red Sea & $\begin{array}{l}\text { Red Sea (Sowinsky 1897, } \\
\text { 1898; Stebbing 1906) }\end{array}$ & $?$ & $?$ & 7 \\
\hline $\begin{array}{l}\text { Leucothoe crenatipalma } \\
\text { Ledoyer, } 1972\end{array}$ & Madagascar & $\begin{array}{c}\text { Madagascar } \\
\text { (Ledoyer 1979, 1986) }\end{array}$ & $24-34$ & $?$ & 4 \\
\hline $\begin{array}{l}\text { Leucothoe ctenochir } \\
\text { K.H. Barnard, } 1925\end{array}$ & $\begin{array}{l}\text { Port Shepstone, } \\
\text { South Africa }\end{array}$ & $\begin{array}{l}\text { South Africa (Griffiths 1974b, } \\
\text { 1974c, 1975); Madagascar } \\
\text { (Ledoyer 1979, 1986) }\end{array}$ & $0-105$ & among coral & 5.5 \\
\hline $\begin{array}{l}\text { Leucothoe dentata } \\
\text { Ledoyer, } 1972\end{array}$ & $\begin{array}{l}\text { Tulear, } \\
\text { Madagascar }\end{array}$ & Madagascar (Ledoyer 1986) & $3-48$ & $\begin{array}{l}\text { muddy sand, } \\
\text { among coral }\end{array}$ & 4 \\
\hline $\begin{array}{l}\text { Leucothoe euryonyx } \\
\text { (Walker, 1901) }\end{array}$ & $\begin{array}{c}\text { Cannes, } \\
\text { Mediterranean }\end{array}$ & \#Madagascar (Ledoyer 1986) & $?$ & $?$ & 2.5 \\
\hline $\begin{array}{l}\text { *Leucothoe furina } \\
\text { (Savigny, 1816) }\end{array}$ & Suez Canal & $\begin{array}{c}\text { \#Sri Lanka (Walker 1904); } \\
\text { Maldives (Walker 1905); } \\
\text { Red Sea (Walker 1909; } \\
\text { Schellenberg 1928; K.H. } \\
\text { Barnard 1937; Ruffo 1969; } \\
\text { \#Lowry \& Stoddart 2003); } \\
\text { South Arabian coast (Ruffo } \\
\text { 1938; Rudwick 1951); } \\
\text { \#Thailand (Ledoyer 1979; } \\
\text { Bussarawich 1984) }\end{array}$ & $8-50$ & $\begin{array}{l}\text { ascidians, } \\
\text { sand, } \\
\text { Chaetopterus }\end{array}$ & $6-10$ \\
\hline
\end{tabular}




\begin{tabular}{|c|c|c|c|c|c|}
\hline Species & Type locality & Additional reports & $\begin{array}{l}\text { Depth } \\
\text { (m) }\end{array}$ & Host & $\begin{array}{c}\text { Size } \\
(\mathrm{mm})\end{array}$ \\
\hline $\begin{array}{l}\text { Leucothoe hyhelia } \\
\text { J.L. Barnard, } 1965\end{array}$ & Marshall Islands & $\begin{array}{c}\text { \#Madagascar (Ledoyer } \\
\text { 1978, 1979, 1986); } \\
\text { \#Tonga (Myers, 1986) }\end{array}$ & $0-34$ & among coral & 3.4 \\
\hline $\begin{array}{l}\text { Leucothoe laticoxa } \\
\text { Ledoyer, } 1978\end{array}$ & $\begin{array}{l}\text { Nosy-Bé, } \\
\text { Madagascar }\end{array}$ & Madagascar (Ledoyer 1986) & $250-550$ & $?$ & 5 \\
\hline $\begin{array}{l}\text { Leucothoe lihue } \\
\text { J.L. Barnard, } 1970\end{array}$ & Oahu, Hawaii & $\begin{array}{c}\text { \#Madagascar (Ledoyer 1978, } \\
\text { 1979, 1986) }\end{array}$ & $0-33$ & black coral & 3 \\
\hline $\begin{array}{l}\text { Leucothoe macrodonta } \\
\text { Ledoyer, } 1986\end{array}$ & $\begin{array}{l}\text { Nosy-Bé, } \\
\text { Madagascar }\end{array}$ & - & $245-255$ & among coral & 8 \\
\hline $\begin{array}{l}\text { Leucothoe madrasana } \\
\text { Sivaprakasam, } 1969\end{array}$ & Madras, India & $\begin{array}{c}\text { \#Madagascar (Ledoyer 1972, } \\
\text { 1978, 1979, 1986) }\end{array}$ & $0-34$ & $\begin{array}{l}\text { holothurians, } \\
\text { among coral }\end{array}$ & $3-5$ \\
\hline $\begin{array}{l}\text { Leucothoe micronesiae } \\
\text { J.L. Barnard, } 1965\end{array}$ & Caroline Islands & $\begin{array}{c}\text { \#Madagascar (Ledoyer 1978, } \\
\text { 1979, 1986) }\end{array}$ & $0-400$ & $\begin{array}{l}\text { algae, among } \\
\text { coral }\end{array}$ & 2.5 \\
\hline $\begin{array}{l}+ \text { Leucothoe } \\
\text { predenticulata Ledoyer, } \\
1978\end{array}$ & $\begin{array}{l}\text { Mauritius, } \\
\text { Madagascar }\end{array}$ & Madagascar (Ledoyer 1986) & $0-25$ & among coral & 4 \\
\hline $\begin{array}{l}\text { Leucothoe richiardii } \\
\text { Lessona, } 1865\end{array}$ & $\begin{array}{c}\text { Genova, } \\
\text { Mediterranean }\end{array}$ & $\begin{array}{l}\text { \#South Africa (K.H. Barnard } \\
\text { 1916; Griffiths 1974b, } \\
\text { 1974c, 1975); } \\
\text { \#Madagascar (Ledoyer 1979, } \\
\text { 1986) }\end{array}$ & $0-255$ & among coral & $6-8$ \\
\hline $\begin{array}{l}\text { *Leucothoe safiae Lyons } \\
\text { \& Myers, } 1991\end{array}$ & Aqaba, Jordan & - & $5-10$ & $?$ & 3.6 \\
\hline $\begin{array}{l}\text { +Leucothoe squalidens } \\
\text { Ledoyer, } 1984\end{array}$ & New Caledonia & Madagascar (Ledoyer 1986) & $?$ & $\begin{array}{l}\text { seagrass, } \\
\text { among coral }\end{array}$ & 3 \\
\hline $\begin{array}{l}\text { Leucothoe stegoceras } \\
\text { Walker, } 1904\end{array}$ & Singapore & $\begin{array}{l}\text { Sri Lanka (Stebbing 1906; } \\
\text { Walker 1909); } \\
\text { East Africa (Walker 1909) }\end{array}$ & $?$ & ascidian & 6 \\
\hline $\begin{array}{l}\text { Nepanamixis grossimana } \\
\text { (Ledoyer, 1978) }\end{array}$ & $\begin{array}{l}\text { Mauritius, } \\
\text { Madagascar }\end{array}$ & Madagascar (Thomas 1997) & $0-25$ & among coral & 3 \\
\hline $\begin{array}{l}\text { *Paranamixis bocki } \\
\text { Schellenberg, } 1938\end{array}$ & Gilbert Islands & $\begin{array}{l}\text { \#Mauritius (Ledoyer 1967); } \\
\text { \#Red Sea (Ruffo 1969) }\end{array}$ & $2-3$ & Seriatopora & 3 \\
\hline $\begin{array}{l}\text { Paranamixis clarkae } \\
\text { Thomas, } 1997\end{array}$ & Seychelles & - & $1-2$ & $\begin{array}{l}\text { coral rubble, } \\
\text { algae }\end{array}$ & 3 \\
\hline $\begin{array}{l}\text { Paranamixis excavatus } \\
\text { Ledoyer, } 1978\end{array}$ & $\begin{array}{l}\text { Mauritius, } \\
\text { Madagascar }\end{array}$ & Madagascar (Thomas 1997) & $0-25$ & among coral & 3 \\
\hline $\begin{array}{l}\text { Paranamixis indicus } \\
\text { Sivaprakasam, } 1968\end{array}$ & $\begin{array}{l}\text { Gulf of Mannar, } \\
\text { Madras, India }\end{array}$ & $\begin{array}{l}\text { Gulf of Mannar, Madras, } \\
\text { India (Thomas 1997) }\end{array}$ & littoral & sponges & 3 \\
\hline $\begin{array}{l}\text { Paranamixis } \\
\text { madagascarensis } \\
\text { Ledoyer, } 1982\end{array}$ & $\begin{array}{l}\text { Mauritius, } \\
\text { Madagascar }\end{array}$ & $\begin{array}{l}\text { Mauritius, Madagascar } \\
\text { (Thomas 1997) }\end{array}$ & $0-4$ & among coral & 3 \\
\hline
\end{tabular}




\title{
Results
}

\author{
Subphylum Crustacea Brünnich, 1772 \\ Class Malacostraca Latreille, 1802 \\ Order Amphipoda Latreille, 1816 \\ Family Leucothoidae Dana, 1852
}

Genus Leucothoe Leach, 1814

\section{Type species}

Cancer articulosus Montagu, 1804.

\section{Leucothoe acanthopus Schellenberg, 1928}

Figs 1-2

Leucothoe acanthopus Schellenberg, 1928: 637-638, fig. 1 (re-description).

Leucothoe acanthopus - Ruffo 1969: 11.

\section{Diagnosis}

Head anterior margin rounded. Maxilla 1 palp 1-articulate, margins constricted. Gnathopod 1 carpus curved; dactylus talon-like. Gnathopod 2 carpus reaching 0.4 times propodus length; propodus palm smooth; dactylus distally tapered and very thin. Pereopods 5-7 bases very narrowly expanded.

\section{Material examined}

\section{Neotype}

RED SEA: O̊, 3.3 mm, Suez Canal, 1924, E. Bannwarth leg. (MNHB-21542a).

\section{Additional material examined}

RED SEA: Õ, 2.9 mm, Suez Canal, 1924, E. Bannwarth leg. (MNHB-21542b) (original type material).

\section{Redescription}

\section{Male}

LENGTH. $3.3 \mathrm{~mm}$.

HEAD. Anterior margin rounded, anterodistal margin evenly rounded, distal margin straight; ventral cephalic keel anterior margin transverse, anteroventral margin rounded, ventral margin straight; eyes present with many ommatidia, round. Antenna 1 length 0.2 times body length, flagellum 3 -articulate, peduncle article 1 less than 2 times as wide as article 2, accessory flagellum present, 1-articulate. Antenna 2 length 0.2 times body length, shorter than antenna 1, flagellum 3-articulate. Mandibular palp ratio of articles 1-3 1.0:2.8:1.5, article 2 with 1 distal seta, article 3 bare, left and right mandibles and upper lip lost in dissection. Lower lip inner lobes fused, setose; outer lobes with large gape, anterior margins setose. Maxilla 1 palp 1-articulate, margins constricted, with 3 distal setae; outer plate with 2 distal robust setae and 7 distal setae. Maxilla 2 inner and outer plates each with 3 distal setae. Maxilliped inner plates distal margin rounded with v-shaped indentation, with several small robust setae; outer plate inner margin smooth, reaching 1.2 times palp article 1, with simple marginal seta; palp article 4 subequal in length with article 3 , distally acute.

Pereon. Coxae 1-4 relative widths: $1.0: 1.3: 1.4: 1.6$. Gnathopod 1 coxa smooth, bare, anterodistal margin produced, rounded, distal margin rounded, posterior margin excavate; basis slightly inflated, 


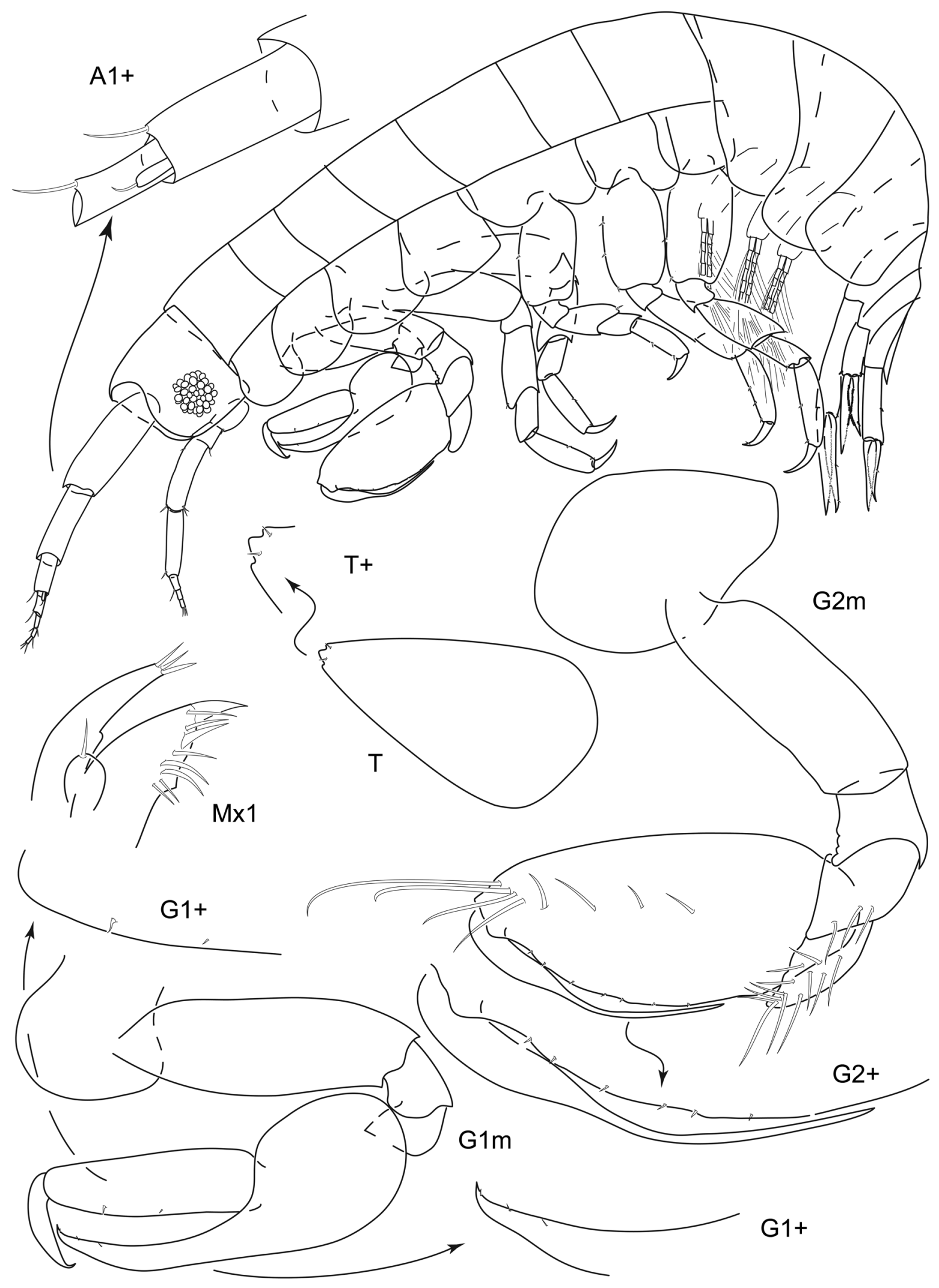

Fig. 1. Leucothoe acanthopus Schellenberg, 1928, neotype, ô, length 3.3 mm (MNHB-21542a). 


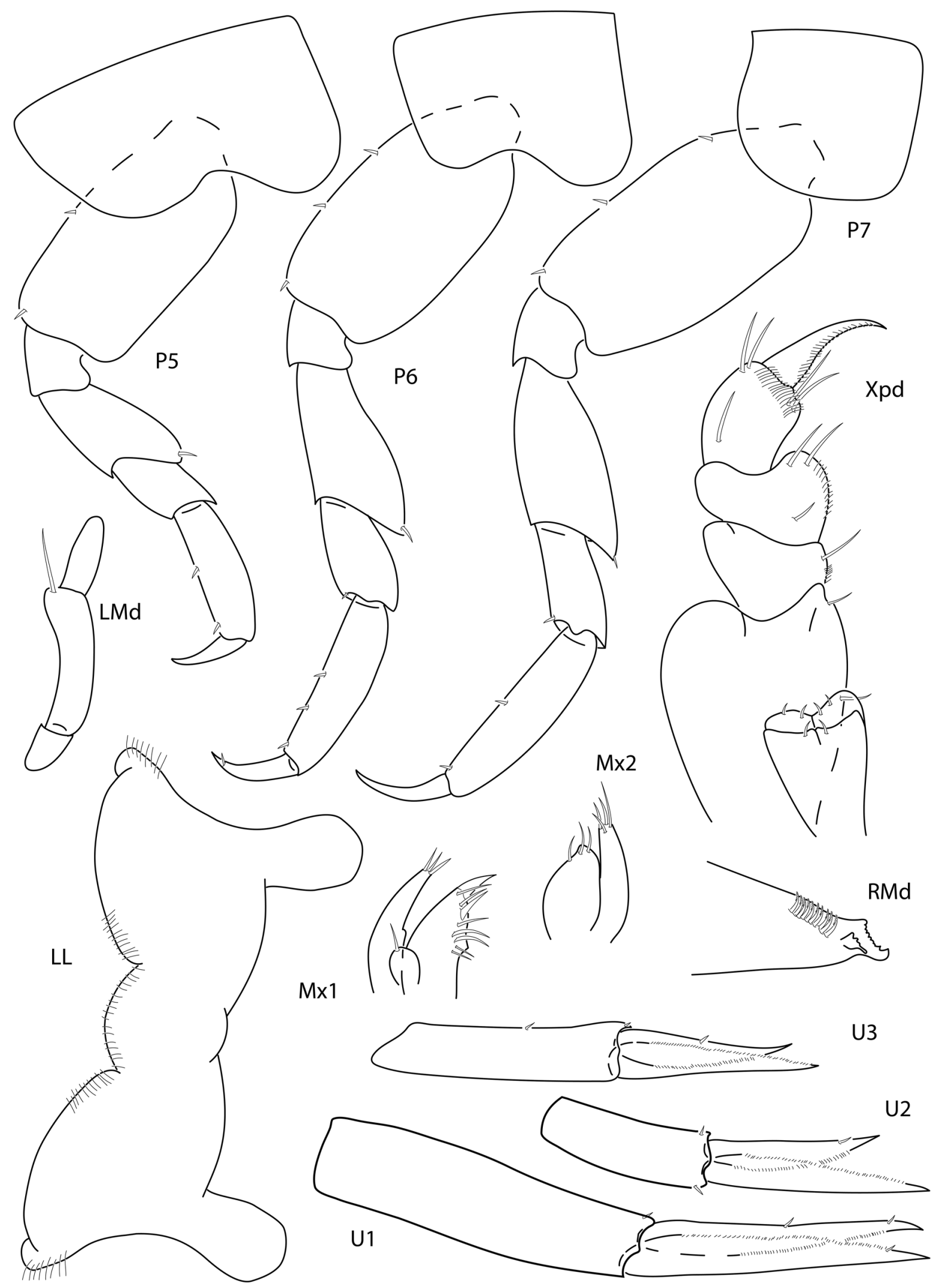

Fig. 2. Leucothoe acanthopus Schellenberg, 1928, neotype, ô, length $3.3 \mathrm{~mm}$ (MNHB-21542a). 
anterior and posterior margins bare; ischium bare; carpus curved, distal length 7.0 times width, proximal margin smooth; propodus straight, palm smooth with 2 small distal setae; dactylus smooth, talon-like, reaching 0.5 times propodus length. Gnathopod 2 coxa broader than long, subequal to coxa 3 , smooth, bare, anterior margin rounded, anterodistally rounded, distal margin rounded, posterior margin slightly excavate; basis straight, anterior and posterior margins bare; carpus 0.4 times propodus length, curved, distally tapered, anterior margin smooth; propodus with 1 mediofacial setal row reaching 0.6 times propodus length, posterior margin smooth, palm convex, smooth; dactylus curved, reaching 0.6 times propodus length, proximal margin smooth, bare, anterior margin distally tapered, acute. Pereopod 3 coxa length 0.9 times width, anterodistal corner overriding distal face of coxa 2 , smooth, anterior margin rounded, distal margin rounded, posterior margin slightly excavate. Pereopod 4 coxa smooth, anterior margin tapered, distal margin slightly produced, posterior margin tapered. Pereopods 5-7 bases widthlength ratios $1: 1.9,1: 2.0,1: 1.9$, posterior margins smooth, bare.

Pleon. Epimera 1-3 bare, epimeron 3 posteroventral corner rounded. Uropods 1-3 relative lengths 1.0: 0.6: 0.7. Uropod 1 peduncle length 1.1 times inner ramus length, outer ramus 0.9 times inner ramus length. Uropod 2 peduncle length 0.8 times inner ramus length, outer ramus 0.8 times inner ramus length. Uropod 3 peduncle subequal in length with inner ramus, outer ramus 0.8 times inner ramus length. Uropod 1 inner and outer rami and uropods $2-3$ outer ramus with robust setae, uropods $1-3$ inner margins of inner and outer rami lined with fine setae. Telson 1.9 times longer than wide, apex tridentate.

Female (sexually dimorphic characters) Unknown.

\section{Distribution}

Red Sea: Suez Canal (Schellenberg 1928; present study), Dahlak Archipelago (Ruffo 1969).

\section{Depth range}

Unknown.

\section{Remarks}

In the text about the single specimen of $3.8 \mathrm{~mm}$ from the Dahlak Archipel offEritrea, Ruffo (1969) stresses the only difference to the original description is a lanceolate-acuminate telson tip instead of a truncate one, but this is already illustrated in Schellenberg (1928). Leucothoe acanthopus shares characters such as the uni-articulate maxilla 1 palp and short gnathopod 1 dactylus with the new generic-level clade documented in White \& Reimer (2012). The relationships of these species need further examination to determine if they should be placed in a different genus. The host for this species is unknown.

\section{Leucothoe acutilobata Ledoyer, 1978}

Fig. 3A

Leucothoe acutilobata Ledoyer, 1978: 295-97, fig. 36.

\section{Type locality}

Mauritius.

\section{Material examined}

ISRAEL: 3 specimens, Eilat, stn 108, 4 May 1969, U. Schiecke leg. (MVR). 
SUDAN: 2 specimens, Port Sudan, stn 154, Dec. 1970, U. Schiecke leg.; 6 specimens, Massa Sheik Ibrahim near Port Sudan, stn 173, 14 Dec. 1970, U. Schiecke leg.; 6 specimens, same locality and date as previous, stn 175, U. Schiecke leg.; 2 specimens, Massa Arakiyai near Port Sudan, from sponge, 1-3 m, 8 Dec. 1970, U. Schiecke leg.; 11 specimens, same locality and date as previous, U. Schiecke leg. All material deposited at MVR.

\section{Distribution}

Red Sea (present study); Western Indian Ocean: Madagascar, Mauritius (Ledoyer 1978).

A

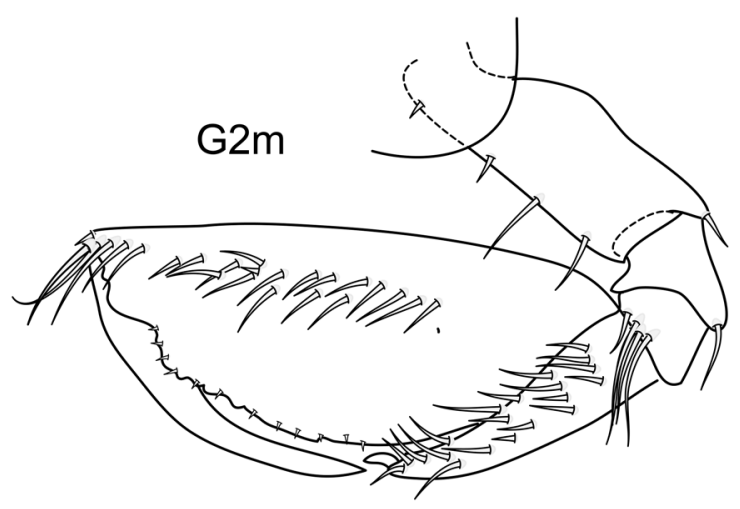

G2lj

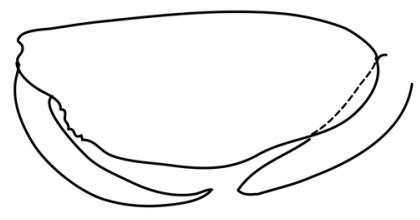

P6
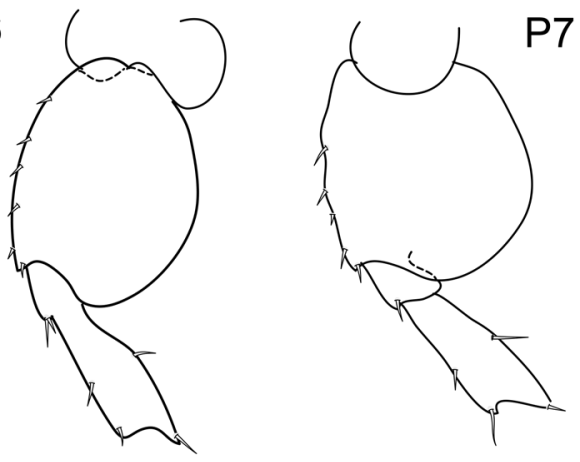
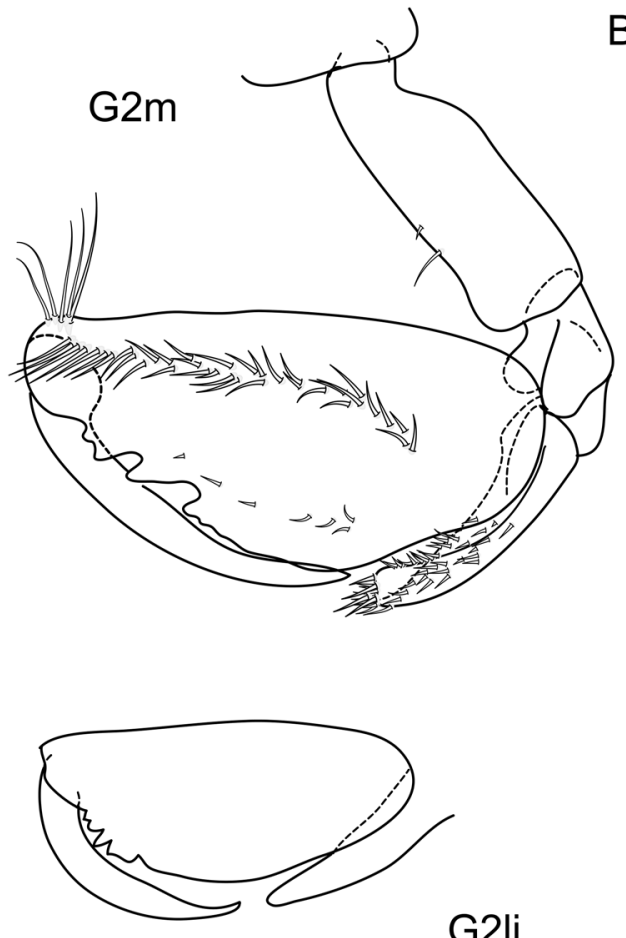

G2lj

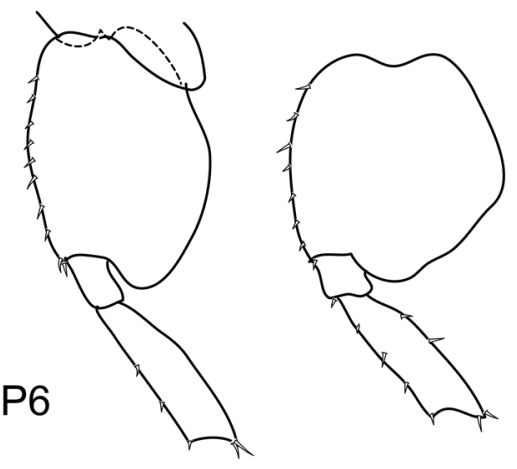

Fig. 3. A. Leucothoe acutilobata Ledoyer, 1978, + , length $6.0 \mathrm{~mm}$. B. Leucothoe predenticulata Ledoyer, 1978, length $4.5 \mathrm{~mm}$. 


\section{Remarks}

Differences between this species and L. predenticulata Ledoyer, 1978 are difficult to determine (see Ledoyer 1978: 300 and this paper), but the posterodistal lobes of the bases of pereopods 5-7 are always clearly lengthened and widened in regular progression, and the inferior half of the posterior margin of pereopod 7 is evenly rounded (vs abrupt corner in the middle in L. predenticulata). Young specimens have a gnathopod 2 propodus palm nearly smooth; the serrations become more visible with age, but remain regular (vs irregular in L. predenticulata). Mature specimens of this species can reach 5-6 mm, while most of the collected material is $3.5-4.5 \mathrm{~mm}$, similar to $L$. predenticulata.

\section{Ecology}

This species has been collected among sponges (present study) and among coral (Ledoyer 1978).

Leucothoe alani sp. nov. urn:1sid:zoobank.org:act:9D0B6878-4468-4052-9C4F-CAACFA17202C

Leucothoella bannwarthi Myers, 1985: 94, figs 74-75.

?Leucothoella bannwarthi - Barnard 1965: 492 , fig. 7.

?Leucothoella banwarthii [sic] - Myers 2013: 307.

\section{Diagnosis}

Coxal plates 2-7 clearly wider than deep, coxae 1 and 2 anterodistally serrate with acute tip, coxa 4 smooth, anterodistal corner with blunt tip. Gnathopod 1 dactylus reaching half the length of propodus. Gnathopod 2 propodus palm reguarly scalloped with 2-3 distal humps. Uropod 3 ratio of inner to outer rami $2: 1$, inner ramus equal to length of peduncle. Telson relatively short and broad, distally rounded.

\section{Etymology}

With gratitude, reminding our friendship with Alan Myers; especially long-lasting with the second author.

\section{Type material}

\section{Holotype}

FIJI: ${ }^{\top}$, Viti Levu, Nasese, $18^{\circ} 10^{\prime} \mathrm{S}, 178^{\circ} 27^{\prime} \mathrm{E}$, shoreward margin of inner moat, 7 Aug. 1979 (AM P35299).

\section{Additional material}

Deposited in Alan Myers' own collection.

\section{Description}

LENGTH. 2.2-2.5 mm.

HEAD. Antennae 1 and 2 about half length of body. Antenna 1 flagellum less than half length of peduncle, 6-articulate, accessory flagellum 1-articulate. Antenna 2 flagellum less than length of peduncle, 5-articulate.

PeREON. Coxa 1 anterior margin serrate, anterodistal corner acute, deeper than wide. Gnathopod 1 carpus proximally rounded, process elongate and slender, distally curved; propodus length 5 times width; dactylus about half length of propodus. Gnathopod 2 coxa almost twice as wide as deep, anterior margin 
serrate, anterodistal corner with acute lengthened tooth; carpus elongate, with distal strong spine; propodus length greater than 2 times width, palm oblique, regularly scalloped distally with $2-3$ humps; dactylus fitting palm which is longer than half propodus length. Coxa 4 anterodistal margin produced, corner blunt.

Pleon. Epimera 1-3 posterodistally rounded. Uropods 1-3 relative lengths 1.0: 0.6: 0.9. Uropod 1 peduncle subequal in length with inner ramus, outer ramus 0.9 times inner ramus length. Uropod 2 peduncle 0.4 times inner ramus length, outer ramus 0.7 times inner ramus length. Uropod 3 peduncle subequal in length with inner ramus, outer ramus 0.6 times inner ramus length. All uropods bare. Telson length-width ratio $3: 2$, distally rounded.

\section{Ecology}

Collected among Halimeda, sponges, including Melophlus sarasinorum Thiele and coral rubble.

\section{Distribution}

Fiji (Myers 1985); Micronesia: Ifaluk Atoll (Barnard 1965); Palau (Myers 2013).

\section{Remarks}

As we generally do not believe in a widespread distribution of leucothoid species, it was tempting to check carefully the admitted morphological similarity to the type material of L. bannwarthi from the Suez Channel. The species here described is clearly smaller in size and mainly presents differences in the structure of the urosome: the telson is short and rounded, and uropod 3 rami are very different in length (the inner about twice the length of the outer).

Leucothoe bannwarthi (Schellenberg, 1928)

Figs $4-5$

Leucothoella bannwarthi Schellenberg, 1928: 638-640, fig. 199.

Leucothoella bannwarthi-Monod 1937: 13, fig. 8. — Barnard 1937: 153. — Schellenberg 1938: 26. Ruffo 1969: 11-12. — Ledoyer 1967: 127, fig. 5A; 1972: 250; 1978: 300; 1979a: 107, fig. 68/1; 1986: 680, fig. 262.

non Leucothoella bannwarthi - Barnard 1965: 492, fig. 7. - Olerød 1970: 370. - Myers 1985: 4, figs 4-75. - Ortiz \& Lalana 1997: 108.

non Leucothoella banwarthii [sic] - Myers 2013: 307.

\section{Type material}

Type material collected by Schellenberg and deposited at the Berlin Museum, MNHB-19936 (examined).

\section{Type locality}

Suez Channel, Red Sea.

\section{Additional material examined}

SUDAN: 19 specimens, Port Sudan, stn 160, Dec. 1970, U. Schiecke leg.; 19 specimens, Port Sudan, stn 168, Dec. 1970, U. Schiecke leg. (slide MVRCr 7726); 1 đ, 3 mm, Port Sudan, stn 188, Dec. 1970, U. Schiecke leg. (slide MVRCr 7731); 54 specimens, same data as previous; 1 ( (ovigerous), $3 \mathrm{~mm}$, near Port Sudan, Marsa Arakiyai, stn 195, 1-3 m, sponge, 12 Aug. 1970, U. Schiecke leg. (slide MVRCr

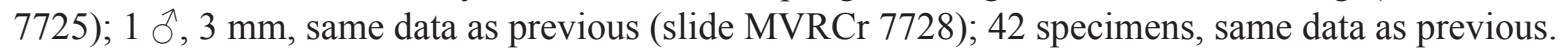




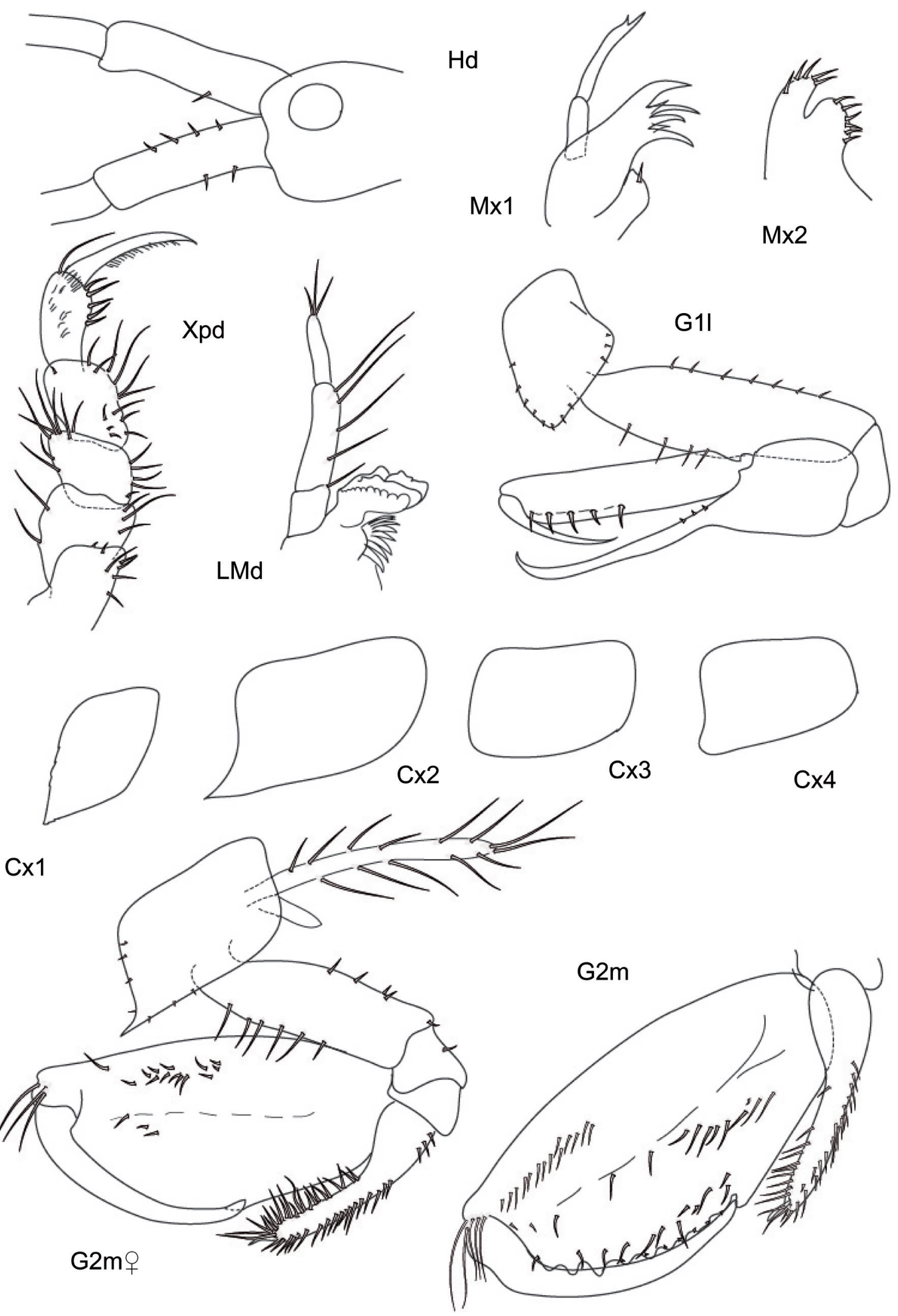

Fig. 4. Leucothoe bannwarthi (Schellenberg, 1928), Ô, length $3.0 \mathrm{~mm}$ (MCRCr 7726); + , length $3.0 \mathrm{~mm}$ (MVRCr 7725). 


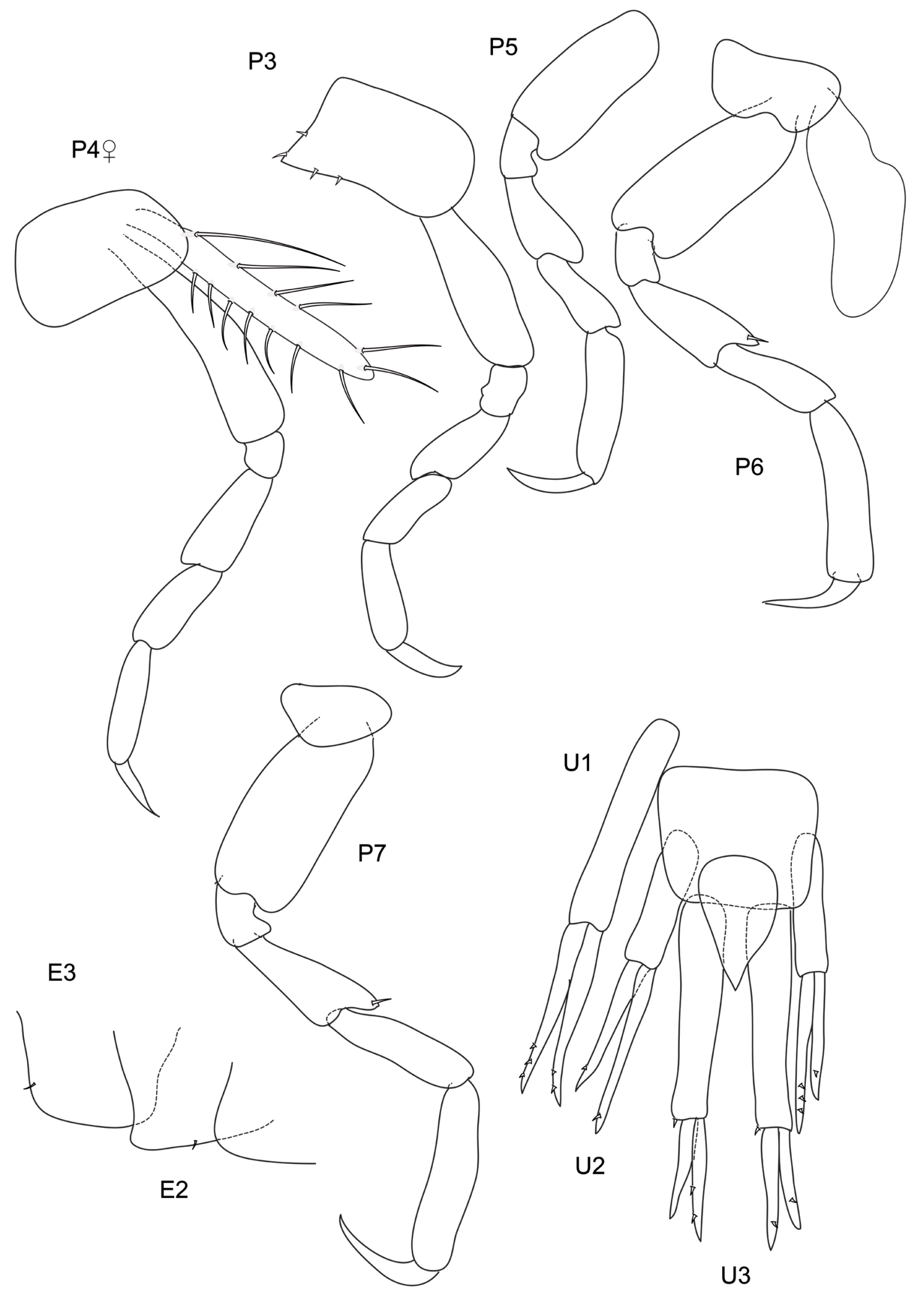

Fig. 5. Leucothoe bannwarthi (Schellenberg, 1928), §̂, length $3.0 \mathrm{~mm}$ (MCRCr 7726); ㅇ, length $3.0 \mathrm{~mm}$ (MVRCr 7725). 


\section{Diagnosis (male)}

Head anterior margin rounded. Coxa 1 trapezium-shaped, antero-distal corner acute, rounded in larger ones (due to abrasion?). Gnathopod 1 carpus curved; dactylus reaching 0.5 times propodus length. Gnathopod 2 carpus reaching 0.4 times propodus length; propodus palm scalloped. Pereopods 5-7 bases rectolinear, posterodistal corner lengthened but not widened. Telson distally acute.

\section{Redescription}

LENGTH. 3-3.3 mm.

HEAD. Anterior margin rounded, anterodistal margin evenly rounded, distal margin straight; eyes present with more than 10 ommatidia, round. Antenna 1 about half body length, flagellum 8 -articulate, peduncle article 1 width less than 2 times article 2, accessory flagellum 1-articulate. Antenna 2 subequal in length with antenna 1, flagellum 8-articulate. Mandibular palp ratio of articles 1-3 1.0:2.4:1.5, article 2 with marginal setae, article 3 with distal setae. Maxilla 1 palp 2-articulate. Maxilla 2 inner and outer plates each with several short distal setae. Maxilliped inner plates distal margin rounded, with several small setae; outer plate inner margin smooth, reaching 0.1 times palp article 1, with marginal seta; palp article 4 length 1.3 times article 3 length.

Pereon. Coxae $1-4$ relative widths $1.0: 2.1: 1.6: 1.5$. Gnathopod 1 coxa deeper than wide, smooth or weakly serrate, beset with many short setae on anterior and inferior margin, anterodistal margin pointed in young specimens, rounded in larger ones (due to abrasion?), distal margin straight, posterior margin excavate; basis slightly inflated, anterior and posterior margins with short setae; ischium bare; carpus curved, distal length 16 times width; propodus straight, palm smooth with small subdistal setae; dactylus smooth, reaching 0.5 times propodus length. Gnathopod 2 coxa wider than deep, smooth, beset with short setae, anterior margin concave, anterodistally acutely lengthened with long and thin tooth, distal margin straight, posterior margin not excavate; basis straight, anterior margin with six medium setae, posterior margin with 4 short setae; carpus 0.4 times propodus length, curved, distally tapering, densely setose, with strong distal spine; propodus with primary mediofacial setal row reaching 0.5 times propodus length, secondary mediofacial setal row parallel to anterior margin with three setae, scalloped; dactylus curved, reaching 0.6 times propodus length, smooth, bare, distally tapered. Pereopod 3 coxa rectangular, much wider than deep, smooth, anterior margin rounded, distal margin rounded, posterior margin not excavate. Pereopod 4 coxa anterior margin slightly protruding, anterodistal corner blunt, inferior margin straight. Pereopods 5-7 coxae shallow. Pereopods 5-7 bases width-length ratios $1: 2.9,1: 2.5,1: 2.3$, rectolinear, posterior margins smooth, bare, posterodistal corner rounded, lengthened, but not widened.

PLEON. Epimeron 1 bare, epimera 2-3 each with one seta, epimeron 3 posteroventral corner rounded. Uropods 1-3 relative lengths $1.0: 0.9: 1.1$. Uropod 1 peduncle 1.2 times inner and outer rami lengths, rami subequal in length. Uropod 2 peduncle and outer ramus 0.8 times inner ramus length. Uropod 3 peduncle 1.7 times inner ramus length, outer ramus 0.8 times inner ramus length. All uropods beset with short spines. Telson 1.8 times longer than wide, apex acute.

Female (sexually dimorphic characters)

Gnathopod 2 propodus palm smooth.

\section{Remarks}

In the original description of material from the Suez Channel, Schellenberg (1928) reports a male of $4 \mathrm{~mm}$ and a female of $3.6 \mathrm{~mm}$. Coxa 1 is described as anteriorly and inferiorly serrate, clearly very acuminate and obviously broader than deep. 
Ruffo (1969: 11-12) writes about five specimens from Museri, off Eritrea: "I compared these animals with Schellenberg 1928, Monod 1937 and J.L. Barnard 1965 and find large correspondence besides the coxa 1 , which is much more rounded."

Ledoyer (1979: fig. 68/1) shows the coxa 1 of a specimen from Madagascar with an acute anterior corner of about 60 degrees (no indication of length), while in 1986 (fig. 262) he describes other material from Madagascar, among which a male of $4 \mathrm{~mm}$ shows coxa 1 is similar to ours in the length to width ratio, but also definitely with an acute antero-distal corner, and slightly serrate.

In 1972, Ledoyer describes Leucothoe angusticoxa with an anteriorly pointed coxa 2 and a rounded coxa 1, where the gnathopods would also match quite well with the material here studied. However, pereopods 5-7 bases are in L. angusticoxa much wider and rounded, with telson longer in relation to width and not distally pointed, and uropod 3 rami longer in relation to the peduncle.

Our material is mainly with an anteriorly rounded coxa 1; only in station 188 did we find two smaller specimens with an acute corner. For the moment we assume that these two forms are probably not two different species, and ascribe both to L. bannwarthi.

From outside this region, J.L. Barnard (1965) illustrated material from Micronesia with a male of $2.5 \mathrm{~mm}$ where coxa 1 is deeper than wide, serrate anteriorly and inferiorly.

Myers (1985) also described much smaller specimens from Fiji (male of $2.1 \mathrm{~mm}$ ), with the telson much shorter and rounded, uropod 3 outer ramus 2 times inner ramus length, and coxa 2 anterior margin serrate.

Thus we think that the material from the Red Sea and Madagascar may both deal with Schellenberg's Leucothoe bannwarthi where coxa 1 anterodistal corner is acute but can be smoothed by abrasion, whereas the specimens from the South Pacific (Fiji and Micronesia) are a separate smaller species deserving another name (see L. alani sp. nov. above).

\section{Ecology}

This species was collected among sponges and coral rubble.

\section{Distribution}

Red Sea: Suez Canal (Schellenberg 1928; Monod 1937; K.H. Barnard 1937); Museri Island off Eritrea (Ruffo 1969); Port Sudan (present study).

Leucothoe minoculis sp. nov. urn:1sid:zoobank.org:act:3276B9C4-ECF6-4DB2-895F-938FAED8647D

Figs 6-7

\section{Diagnosis}

Head anterior margin oblique, produced, distal margin excavate with acute projection. Eyes round, rather small. Accessory flagellum present, 2-articulate. Maxilla 1 palp 1-articulate. Gnathopod 1 coxa longer than wide; carpus curved, very thin; propodus proximally not inflated, rectangular; dactylus reaching 0.3 times propodus length. Gnathopod 2 basis rectangular; carpus distally rounded, serrate, with one strong apical spine; propodus palm partially concave with many small tubercles distally. Pereopods 5-7 bases narrowly expanded; meri and carpi posteriorly lengthened and moderately widened. 


\section{Etymology}

Stressing the fact that this species has smaller eyes than the other ones; 'minoculis' (composed from Latin 'minor' = less and 'oculi' = eyes), used as an adjective.

\section{Type material}

\section{Holotype}

ISRAEL: Õ, 5 mm, Red Sea, Eilat, stn 65, Apr.-May 1969, U. Schiecke leg. (ZMB 29752).

\section{Paratype}

ISRAEL: + , $3.5 \mathrm{~mm}$, same data as holotype (slide MVRCr 7729).

\section{Additional material examined}

ISRAEL: 1 ð, $3.5 \mathrm{~mm}$, same data as holotype (slide MVRCr 7730); 2 specimens in alcohol, same data as holotype (MVRCr).

\section{Description}

\section{Male}

\section{LENGTH. $5 \mathrm{~mm}$.}

HEAD. Anterior margin medially acute, anterodistally oblique, inferiorly straight; eyes rather small, round. Antenna 1 length 0.5 times body length, flagellum 6-articulate, peduncle article 1 width subequal to article 2, accessory flagellum present, 2-articulate. Antenna 2 length 0.4 times body length, shorter in length than antenna 1, flagellum 6-articulate. Mandibular palp ratio of articles 1-3 1.0:2.2:1.6, article 2 with several marginal and distal setae, article 3 with 1 distal seta, incisors weakly dentate; left mandible with 5 raker spines, lacinia mobilis large, weakly toothed. Maxilla 1 palp 1-articulate, articulation not well visible, with distal slender setae; outer plate with 5 distal robust setae and additional slender setae. Maxilla 2 inner plate with marginal and distal slender setae, outer plate with distal slender setae. Maxilliped inner plates distal margin rounded, with short simple robust setae; outer plate inner margin smooth, reaching 0.3 times palp article 1; palp article 4 subequal in length with article 3 , distally acute.

Pereon. Coxae 1-4 relative widths $1.0: 1.1: 1.0: 1.3$. Gnathopod 1 coxa smooth, anterodistal margin produced, rounded, distal margin rounded, posterior margin curved; basis distally not expanded, anterior margin with 2 short setae, posterior margin bare; ischium bare; carpus curved, distal length 30 times width, distally very narrow, anterior margin with small short setae; propodus straight, palm smooth with short setae; dactylus smooth, reaching 0.3 times propodus length. Gnathopod 2 coxa subquadrate, wider than coxa 3, smooth, margins straight; basis not expanded, stout, anterior margin with 13 medium setae, posterior margin bare; ischium bare; carpus 0.5 times propodus length, curved, setose, distally rounded, serrate; propodus primary mediofacial setal row reaching 0.8 times propodus length, secondary mediofacial setal row with three setae, anterior margin gently curved, smooth, palm with many small tubercles; palmar corner clearly defined as prominent hump, remaining posterior margin straight; dactylus curved, proximal margin smooth, bare, anterior margin distally acute, reaching 0.6 times propodus length. Pereopod 3 coxa smooth, anterior margin rounded, distal margin slightly rounded, posterior margin straight. Pereopod 4 coxa trapezium-shaped, smooth, antero-distally produced, anterior margin straight, longer than straight posterior one, distal margin scarcely rounded. Pereopods 5-7 bases widthlength ratios $1: 1.9,1: 1.9,1: 1.7$, posterior margins smooth and bare; Pereopods 5-6 bases with anterior and posterior margin nearly parallel, pereopod 7 basis longer and wider than the ones of pereopods 5 and 6 , posteriorly moderately rounded. 

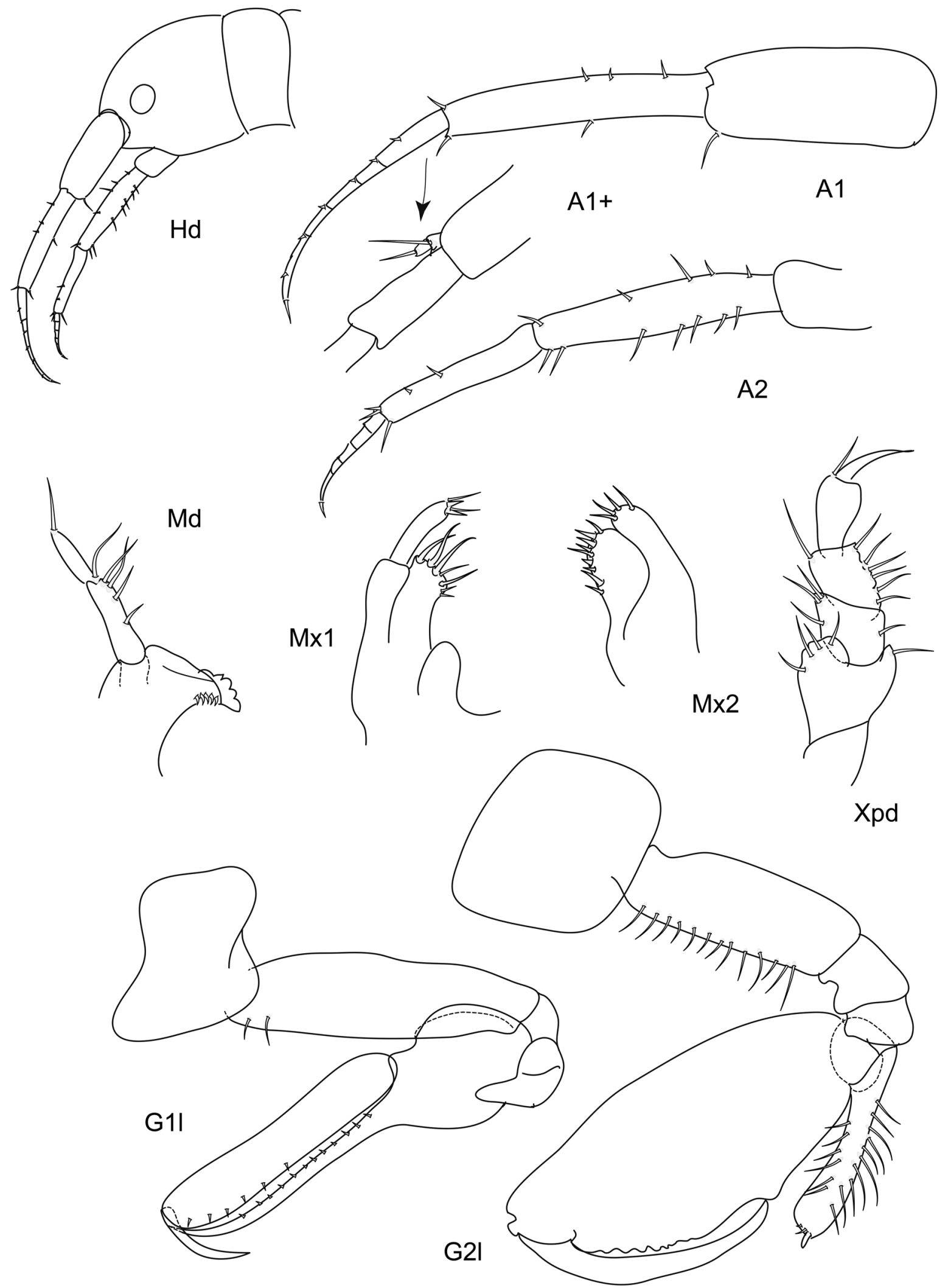

Fig. 6. Leucothoe minoculis sp. nov., holotype, ふૈ, length $5.0 \mathrm{~mm}$ (MVRCr 7729). 


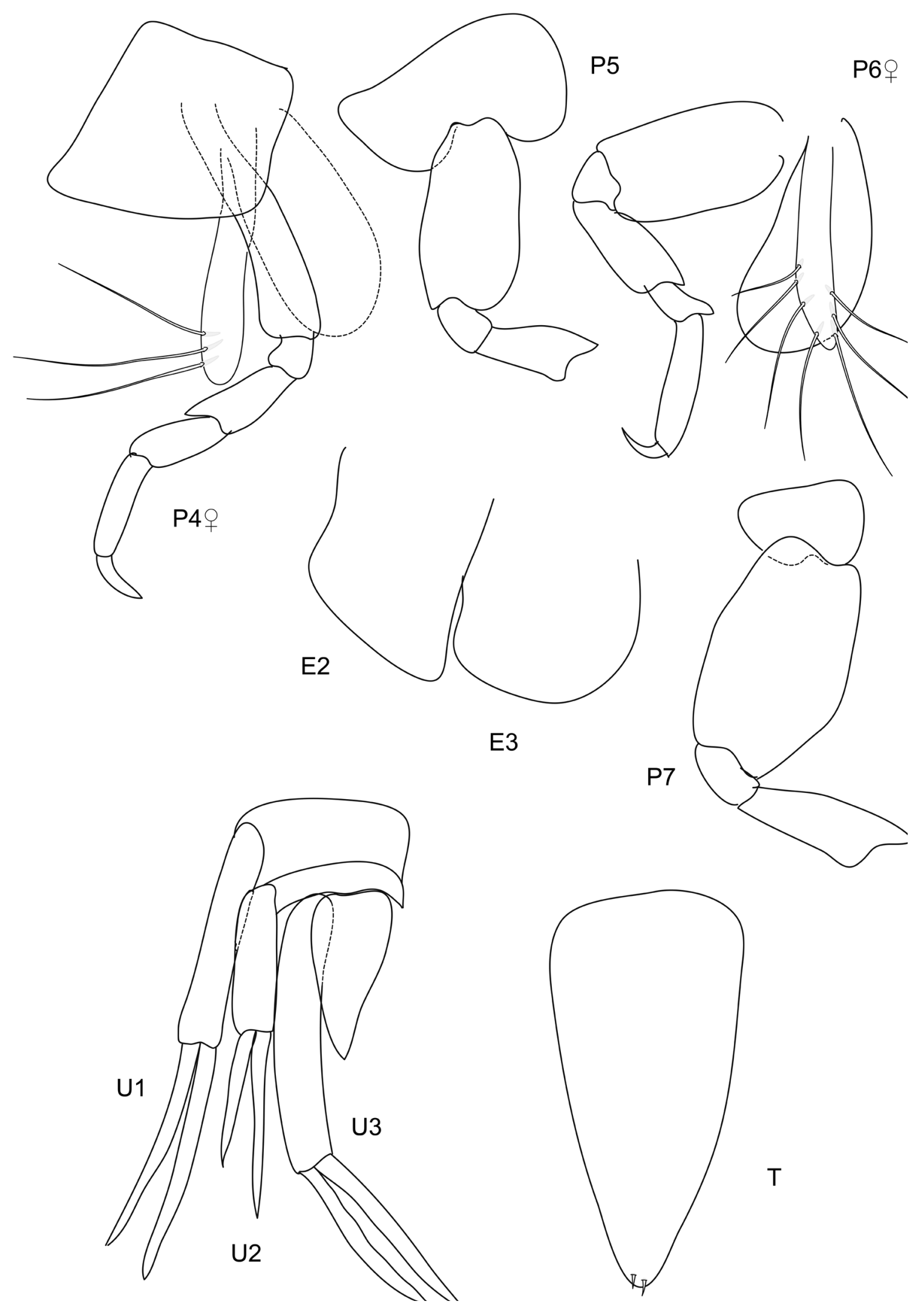

Fig. 7. Leucothoe minoculis sp. nov., holotype, §̂, $5.0 \mathrm{~mm}$ (MVRCr 7729); paratype, + , $3.5 \mathrm{~mm}$ (MVRCr-7729). 
Pleon. Epimera 1-3 bare, epimeron 3 posteroventral corner rounded. Uropods 1-3 relative lengths $1.0: 0.7: 1.0$. Uropod 1 peduncle subequal in length with rami, outer ramus 0.9 times inner ramus length. Uropod 2 peduncle subequal in length with outer ramus, inner ramus about 1.4 times outer ramus length. Uropod 3 peduncle 1.2 times inner ramus length, outer ramus 0.9 times inner ramus length. Uropods 1-3 inner and outer rami bare. Telson 1.8 times longer than wide, apex rounded, beset with two short setae.

Female (sexually dimorphic characters)

Similar in all aspects to male.

\section{Depth range}

Unknown.

\section{Remarks}

Leucothoe minoculis sp. nov. resembles L. reimeri sp. nov. in the shape of the head and the narrowly expanded bases on pereopods 5-7. It differs in having a very small eye, and in the shapes of the coxae. This species is unique in having a 2-articulate accessory flagellum, not documented in any other known species of Leucothoe.

\section{Distribution}

Red Sea (present study).

Leucothoe pansa sp. nov. urn:1sid:zoobank.org:act:EA53097A-C5E3-4B72-B3F8-E07C59D917B4

Figs 8-9

\section{Diagnosis}

Head anterior margin oblique, produced, distal margin excavate with rounded projection. Maxilla 1 palp 1-articulate. Gnathopod 1 coxa broader than long; carpus curved; propodus proximally inflated: dactylus reaching 0.3 times propodus length. Gnathopod 2 basis distally expanded, stout; carpus distally tapered, pointed; propodus palm concave with 2 small tubercles. Pereopods 5-7 bases narrowly expanded; meri and carpi posteriorly expanded.

\section{Etymology}

After the Latin 'pansus', meaning 'stretch, spread, expand' and referring to the distinctly expanded meri of pereopods 5-7, used as adjective.

\section{Type material}

\section{Holotype}

SUDAN: đ̂, 3.4 mm, Port Sudan, Marsa Arakiyai, stn 195, 1-3 m, sponge, 12 Aug. 1970, U. Schiecke leg. (ZMB 29748, slide 5094).

\section{Paratype}

SUDAN: + , $3.2 \mathrm{~mm}$, same data as holotype (ZMB 29749, slide 5095).

\section{Additional material examined}

SUDAN: 1 đ̊, 3 mm, Port Sudan, Dec. 1970. U. Schiecke leg. 


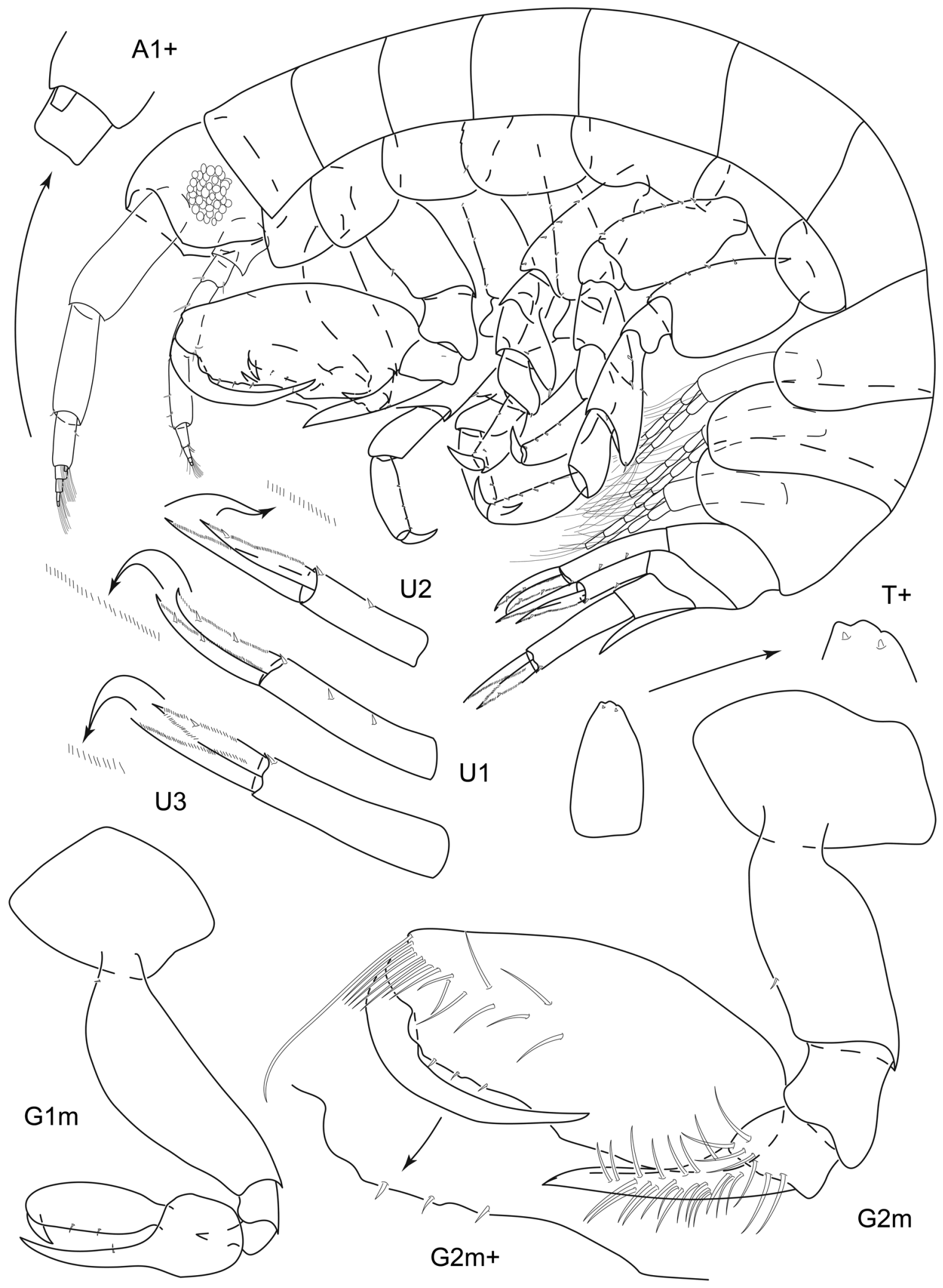

Fig. 8. Leucothoe pansa sp. nov, holotype, ô, length 3.4 mm (ZMB 29748, slide 5094). 


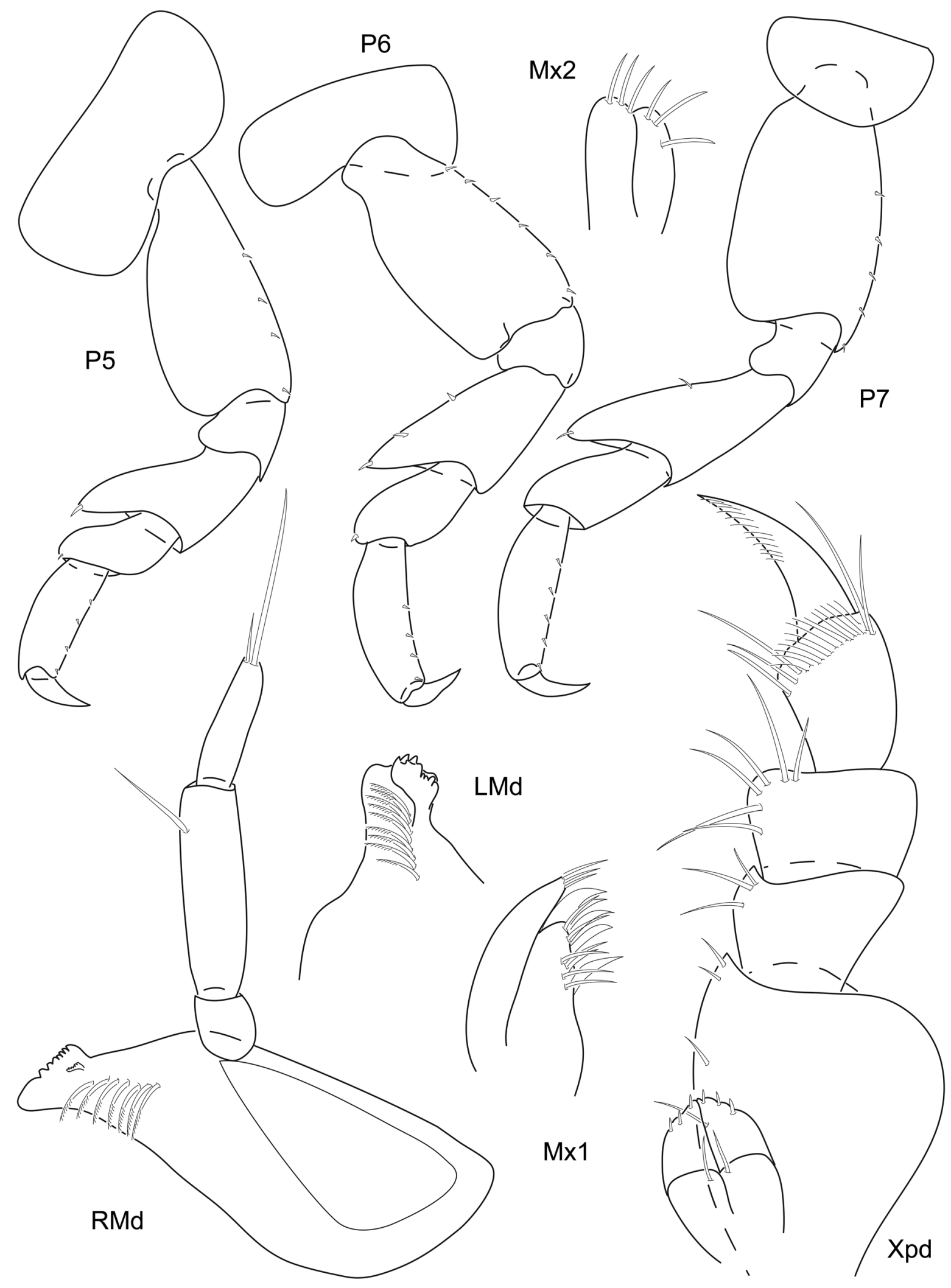

Fig. 9. Leucothoe pansa sp. nov., holotype, đ̂, length 3.4 mm (ZMB 29748, slide 5094). 


\section{Description}

Male

LENGTH. $3.4 \mathrm{~mm}$.

HEAD. Anterior margin oblique, anterodistal margin subquadrate, distal margin straight; ventral cephalic keel anterior margin excavate; anteroventral margin quadrate, ventral margin produced; eyes present with many ommatidia, round. Antenna 10.2 times body length, flagellum 3-articulate, peduncle article 1 width less than 2 times article 2, accessory flagellum present, 1 -articulate. Antenna 2 length 0.18 times body length, shorter in length than antenna 1, flagellum 3-articulate. Mandibular palp ratio of articles 1-3 1.0:2.2:1.3, article 2 with 1 distal seta, article 3 with two distal setae, incisors weakly dentate; left mandible with 8 raker spines, lacinia mobilis large, strongly toothed; right mandible with 7 raker spines, lacinia mobilis very small, weakly toothed. Upper lip asymmetrically lobate, anterior margin weakly setose. Lower lip inner lobes fused, setose; outer lobes with moderate gape, anterior margins setose. Maxilla 1 palp 1 -articulate, with 3 distal slender setae; outer plate with 4 distal robust setae and 7 distal slender setae. Maxilla 2 inner and outer plates each with 3 distal slender setae. Maxilliped inner plates distal margin rounded with v-shaped indentation, with short and long simple setae; outer plate inner margin smooth, reaching 0.2 times palp article 1, with simple marginal setae; palp article 4 subequal in length with article 3 , distally acute.

Pereon. Coxae $1-4$ relative widths $1.0: 1.0: 1.1: 1.3$. Gnathopod 1 coxa smooth, bare, anterodistal margin produced, subquadrate, distal margin straight, posterior margin slightly excavate; basis proximally expanded, anterior and posterior margins bare; ischium bare; carpus curved, distal length 8.5 times width, proximal margin smooth; propodus proximally inflated, palm smooth with 2 distal setae; dactylus smooth, reaching 0.3 times propodus length. Gnathopod 2 coxa broader than long, subequal in size with coxa 3, smooth, bare, anterior margin straight, anterodistally rounded, distal margin straight, posterior margin straight; basis distally expanded, stout, anterior margin with 1 seta, posterior margin bare; carpus 4.8 times propodus length, curved, distally tapered, pointed, anterior margin smooth; propodus with 1 mediofacial setal row at midline, reaching 0.5 times propodus length, posterior margin smooth, palm concave with 2 minor tubercles; dactylus curved, proximal margin smooth, bare, anterior margin distally acute, reaching 0.5 times propodus length. Pereopod 3 coxa length 0.7 times width, anterodistal corner overriding distal face of coxa 2 , smooth, anterior margin rounded, distal margin slightly rounded, posterior margin slightly excavate. Pereopod 4 coxa anterior margin rounded, serrate, distal margin rounded, posterior margin straight. Pereopods 5-7 bases width-length ratios 1:1.9, 1:1.9, 1:1.4, posterior margins smooth, bare; meri and carpi posteriorly expanded.

Pleon. Epimera 1-3 bare, epimeron 3 posteroventral corner rounded. Uropods 1-3 relative lengths $1.0: 0.9: 1.0$. Uropod 1 peduncle 0.7 times inner ramus length, outer ramus subequal in length with inner ramus. Uropod 2 peduncle and outer ramus 0.8 times inner ramus length. Uropod 3 peduncle 1.3 times inner ramus length, outer ramus 0.9 times inner ramus length. Uropod 1 inner ramus with robust setae, uropods 1-3 outer rami with robust seta(e). Uropods 1-3 inner and outer rami lined with fine setae. Telson 1.8 times longer than wide, apex weakly tridentate.

Female (sexually dimorphic characters) Similar in all aspects to male.

\section{Remarks}

Leucothoe pansa sp. nov. shares the characters mentioned for L. acanthopus such as the uni-articulate maxilla 1 palp and short gnathopod 1 dactylus with the sub-species level clade documented in White \& Reimer (2012) as well as the inflated gnathopod 1 propodus. This species is also similar to L. acanthopus in having pereopods 5-7 bases narrowly expanded and a smooth gnathopod 2 propodus 
palm. The gnathopod 2 propodus differs from that of $L$. acanthopus in having a concave palm. The host for this species is an unidentified sponge species (Porifera).

\section{Distribution}

Red Sea (present study).

\section{Depth range}

$1-3 \mathrm{~m}$.

Leucothoe predenticulata Ledoyer, 1978

Fig. 3B

Leucothoe predenticulata Ledoyer, 1978: 299-300, fig. 37.

Leucothoe predenticulata - Ledoyer 1986: 670-672, figs 246, 257.

\section{Type locality}

Mauritius.

\section{Material examined}

ISRAEL: 2 specimens, Eilat S-Reef, stn 14, 1-4 m, with corals, 5 Feb. 1969, U. Schiecke leg.; 2 specimens, Eilat, stn 15, middle-fine to fine sand, Apr.-May 1969, U. Schiecke leg.; 4 specimens, Eilat, stn 51, U. Schiecke leg.

SUDAN: 1 specimen, 4.5 mm, Port Sudan, stn 60, Dec. 1970, U. Schiecke; 1 juv., Port Sudan, stn 66, Dec. 1970, U. Schiecke leg.; 3 specimens, Port Sudan, stn 70, Dec. 1970, U. Schiecke leg.; 2 specimens, Port Sudan, stn 160, Dec. 1970, U. Schiecke leg.; 7 specimens, Port Sudan, Marsa Arakiyai, st 162, Dec. 1970, U. Schiecke leg.; 2 specimens, Port Sudan, Marsa Arakiyai, stn 166, Dec. 1970, U. Schiecke leg.; 11 juvs, Port Sudan, Marsa Arakiyai, stn 168, Dec. 1970, U. Schiecke leg.; 11 specimens, Port Sudan, Marsa Arakiyai, stn 180, Dec. 1970, U. Schiecke leg.; 7 specimens, Port Sudan, Marsa Arakiyai, stn 94, sponge, Dec. 1970, U. Schiecke leg.; 1 specimen, Port Sudan, Flamingo Bay, stn 196, reef and epiphytes, 12 Nov. 1970, U. Schiecke leg.; 2 specimens, same locality and date as previous, stn 198, reef and epiphytes, U. Schiecke leg.; 3 specimens, same locality and date as previous, stn 204, reef and epiphytes, U. Schiecke leg.

\section{Remarks}

Differences between this species and L. acutilobata Ledoyer, 1978 are not readily apparent (see Ledoyer 1978: 300 and this paper), but the posterodistal lobes of the bases of pereopods 5-7 are also scarcely lengthened in young specimens, the posterior margin of pereopod 7 is always with the inferior half straight or somewhat concave, ending with a clear-cut corner at about the middle of the posterior margin and the widest point of the basis (vs regularly rounded in L. acutilobata). In young specimens gnathopod 2 propodus palm is irregularly serrate, and incisions become deeper and wider with age (vs smooth in young specimens and regularly shallowly serrate in adult). This species has been collected among coral (Ledoyer 1978).

\section{Distribution}

Red Sea (present study); Western Indian Ocean: Madagascar, Mauritius (Ledoyer 1978, 1986). 


\section{Leucothoe reimeri sp. nov. urn:1sid:zoobank.org:act:469B3C52-F3F3-439F-B52C-D7C185CEC896}

Figs $10-11$

\section{Diagnosis}

Head unusually small, anterior margin rounded. Right mandible lacinia mobilis with two layers. Eyes large, round. Gnathopod 1 basis distally expanded; carpus and propodus curved. Gnathopod 2 basis proximally expanded, stout; carpus reaching 0.2 times propodus length; propodus palm concave, smooth, with dense row of submarginal spine-setae. Coxae short. Pereopods 5-7 bases narrowly expanded, pereopods $6-7$ bases posterior margins serrate. Telson apex rounded.

\section{Etymology}

Named for James Davis Reimer, the collector. Jamie has provided tremendous support for leucothoid amphipod research over the past several years, always willing to share knowledge and resources, eh.

\section{Type material}

Holotype

RED SEA: Ō, 5.9 mm, Jazirat Burcan, Shi'b Pelam, 2749.003' N, 3506.397' E, 29.8 m, inside sponge, 29 Sep. 2013, J.D. Reimer leg. (ZMB 29750, slide 5096, RS93).

\section{Paratype}

RED SEA: +, 5.5 mm, same station data (ZMB 29751, slide 5097).

\section{Additional material examined}

RED SEA: 2 ô $\hat{\jmath}, 6 \mathrm{~mm}, 3$ juvs, 2-4 mm, same station data (K.N. White pers. coll.).

\section{Description}

Male

LENGTH. $5.9 \mathrm{~mm}$.

HeAD. Small; anterior margin rounded, anterodistal margin rounded, distal margin straight; ventral cephalic keel anterior produced with cusp; anteroventral margin rounded, ventral margin tapered; eyes large, round. Antenna 1 length 0.2 times body length, flagellum 6 -articulate, peduncle article 1 width less than 2 times article 2, accessory flagellum present, 1-articulate. Antenna 2 length 0.2 times body length, subequal in length with antenna 1, flagellum 4-articulate. Mandibular palp ratio of articles 1-3 1.0: 3.4: 2.1, article 2 with 2 distal setae, article 3 with 2 distal setae, incisors weakly dentate; left mandible with 14 raker spines, lacinia mobilis large, weakly toothed; right mandible with 14 raker spines, lacinia mobilis small, weakly toothed, with two layers. Upper lip asymmetrically lobate, anterior margin weakly setose. Lower lip inner lobes fused, setose; outer lobes with large gape, anterior margins setose. Maxilla 1 palp 2-articulate, with 3 distal slender setae; outer plate with 5 distal robust setae and 4 slender setae. Maxilla 2 inner plate with 4 distal slender setae outer plate with 7 distal slender setae and several marginal fine setae. Maxilliped inner plates distal margin rounded with v-shaped indentation, with short simple robust setae; outer plate inner margin smooth, reaching 0.4 times palp article 1 , with simple marginal setae; palp article 4 subequal in length with article 3 , distally acute.

Pereon. Coxae 1-4 relative widths $1.0: 1.4: 1.5: 1.3$. Gnathopod 1 coxa smooth, anterodistal margin produced, rounded, distal margin rounded, posterior margin straight; basis distally expanded, anterior margin with 4 short setae, posterior margin bare; ischium bare; carpus curved, distal length 14.1 times width, proximal margin with two rows of dentition; propodus curved, palm dentate with 8 proximal 


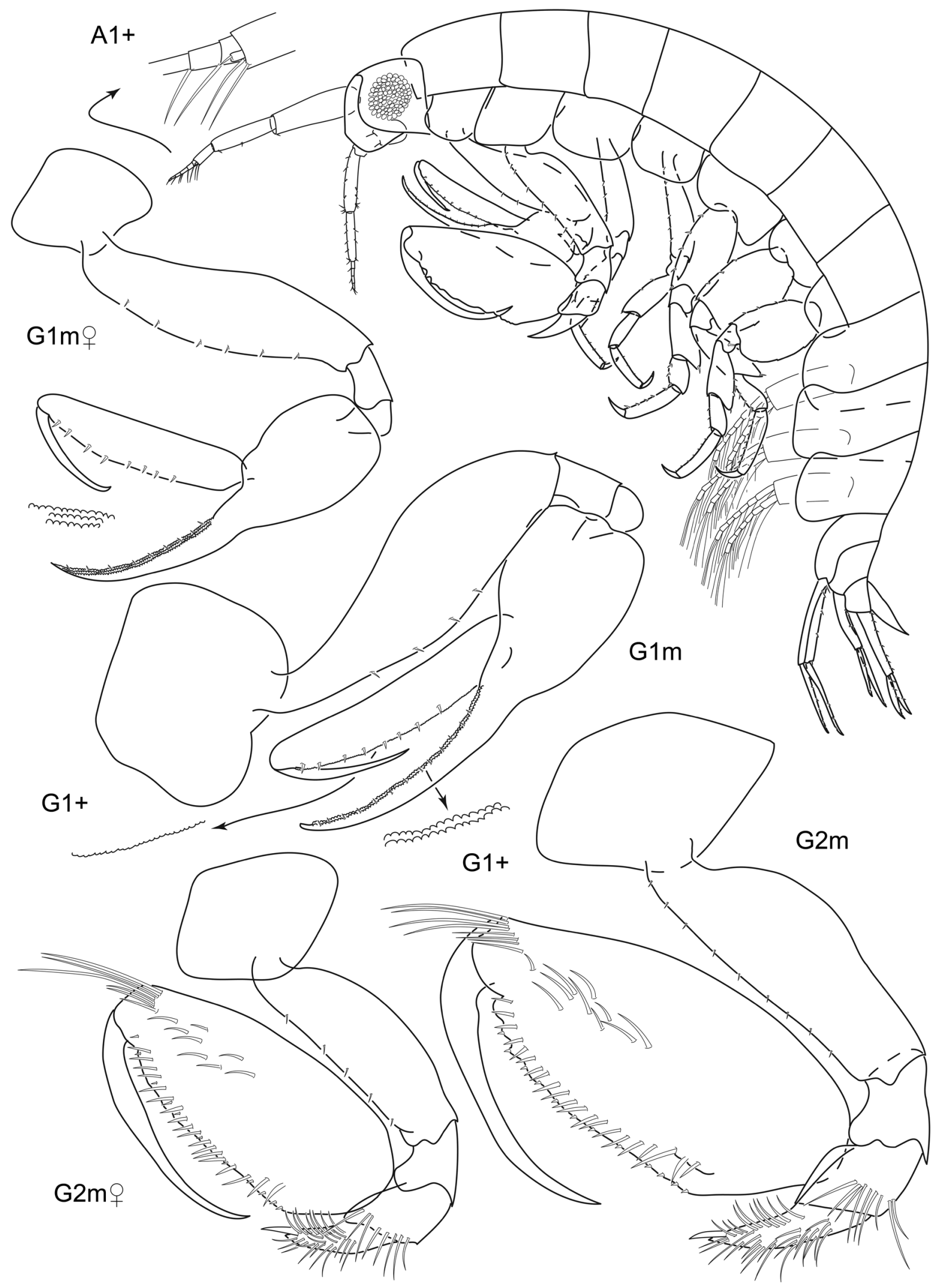

Fig. 10. Leucothoe reimeri sp. nov., holotype, $\partial$, length $5.9 \mathrm{~mm}$ (ZMB 29750, slide 5096); paratype,, , length $5.5 \mathrm{~mm}$ (ZMB 29751, slide 5097). 


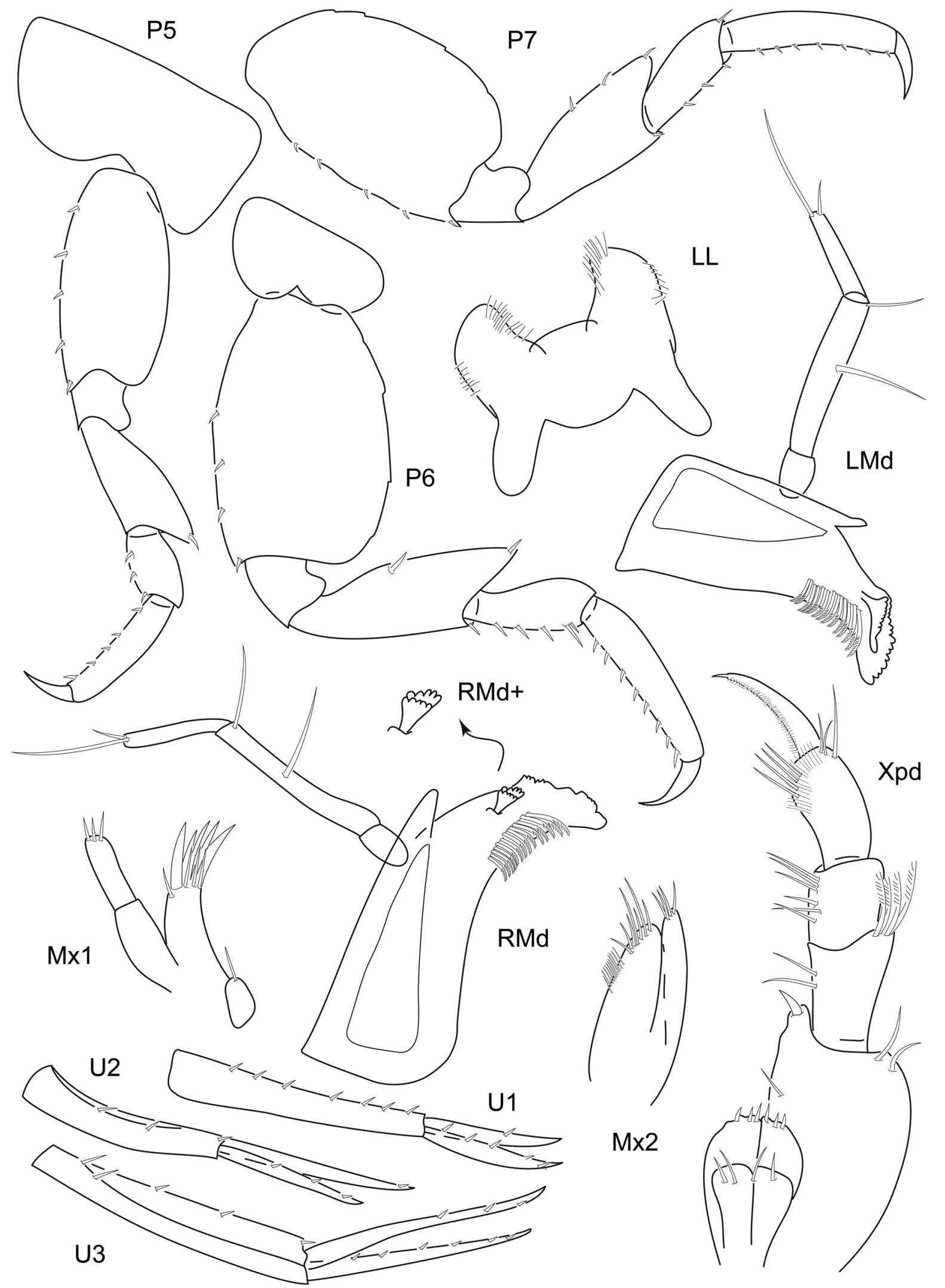

Fig. 11. Leucothoe reimeri sp. nov., holotype, đ̂, length 5.9 mm (ZMB 29750, slide 5096). 
setae; dactylus smooth, reaching 0.4 times propodus length. Gnathopod 2 coxa broader than long, subequal in size with coxa 3 , smooth, anterior margin straight, anterodistally rounded, distal margin straight, posterior margin straight; basis proximally expanded, stout, anterior margin with 9 short setae, posterior margin bare; ischium bare; carpus 0.2 times propodus length, curved, distally tapered, anterior margin smooth; propodus with 1 mediofacial setal row displaced to midline, reaching 0.5 times propodus length, with dense row of submarginal spine-setae, posterior margin smooth, palm convex with 2 minor tubercles; dactylus curved, proximal margin smooth, bare, anterior margin distally acute, reaching 0.6 times propodus length. Pereopod 3 coxa length 0.8 times width, anterodistal corner overriding distal face of coxa 2 , smooth, anterior margin rounded, distal margin slightly rounded, posterior margin straight. Pereopod 4 coxa smooth, anterior margin rounded, distal margin rounded, posterior margin straight. Pereopods $5-7$ bases width to length ratios $1: 2.2,1: 1.4,1: 1.6$, pereopod 5 basis posterior margin smooth, bare; pereopods $6-7$ posterior margins serrate, bare.

Pleon. Epimera 1-3 bare, epimeron 3 posteroventral corner rounded. Uropods 1-3 relative lengths $1.0: 1.0: 1.4$. Uropod 1 peduncle 1.8 times inner ramus length, outer ramus 0.9 times inner ramus length. Uropod 2 peduncle subequal in length with inner ramus, outer ramus 0.8 times inner ramus length. Uropod 3 peduncle 1.2 times inner ramus length, outer ramus 0.9 times inner ramus length. Uropods 1-3 inner and outer rami with robust seta(e). Telson 1.8 times longer than wide, apex rounded.

Female (sexually dimorphic characters)

Gnathopod 1 basis slightly distally expanded, anterior margin with 6 short setae; carpus proximal margin with three rows of dentition. Gnathopod 2 basis slightly proximally expanded, stout, anterior margin with 5 short setae.

\section{Remarks}

Leucothoe reimieri sp. nov. is unique in having a dense row of submarginal spine-setae on the propodus palm. The narrowly expanded pereopod 5-7 bases are similar to those of $L$. acanthopus and L. pansa sp. nov. This species inhabits the interior canals of an unidentified marine sponge.

\section{Distribution}

Red Sea: Shi'b Pelam (present study).

Leucothoe safiae Lyons \& Myers, 1991

Leucothoe safiae Lyons \& Myers, 1991: 607-610, figs 7-8.

Leucothoe richiardii - Ledoyer 1979: 106-108, fig. 66; 1986: 672-673.

non Leucothoe richiardii Lessona, 1865: 427.

\section{Type locality}

Gulf of Aqaba, Red Sea.

\section{Material examined}

ISRAEL: 1 Õ, 4 mm, stn 39, Eilat, U. Schiecke leg., April-May 1969.

\section{Remarks}

There are no sexual differences to the female described in the original paper, except that pereopods 6 and 7 have obviously confounded labels in fig. 8 of Lyons \& Myers (1991). The only addition which seems 
worth mentioning is the rather small head with large round eyes (illustrated but not stressed verbally) and a quite remarkable bulge anteriorly.

Kossman's (1880) description of L. crassimana from the Red Sea is poor; the drawings of the gnathopods, however, would match this species except for the length of $7 \mathrm{~mm}$ (vs 3.6-4 mm here). Ledoyer (1979: 106-108, fig. 66 and 1986: 672-73) named his material, found in Madagascar, L. richiardii Lessona, 1865 but it matches perfectly with the material herein studied, while L. richiardii has Genova (Mediterranean) as the type locality with a length of $6-8 \mathrm{~mm}$. In both mentioned publications he also illustrates the anterior bulge of the head and the deep insertion of antenna 1 .

This species remains the only Leucothoe with a posterodistal tooth on epimeron 3 to have been identified in the Red Sea.

\section{Distribution}

Red Sea (present study), Gulf of Aqaba (Lyons \& Myers 1991); Western Indian Ocean: Madagascar (Ledoyer 1979, 1986).

\section{Leucothoe squalidens Ledoyer, 1984}

Fig. 12

Leucothoe squalidens Ledoyer 1984: 82, fig. 40A.

Leucothoe squalidens - Ledoyer 1986: 679, fig. 261.

\section{Type locality}

New Caledonia.

\section{Material examined}

ISRAEL: 2 juvs, 1.6 mm, Eilat, stn 105, Apr.-May 1969, U. Schiecke leg. (slide MVRCr 7732).

SUDAN: 1 specimen, Port Sudan, stn 160, Dec. 1970, U. Schiecke leg.; 2 specimens, 2 mm, Port Sudan, stn 168, Dec. 1970, U. Schiecke leg. (slide MVRCr 7733).

\section{Remarks}

The name chosen by Ledoyer indicates that the first gnathopods of this species are beset with many very small spines making them look "scaly" on the margins between the very thin propodus and carpus. The dactylus of the first gnathopod is very short; that of the second gnathopod is longer than $3 / 4$ of the propodus hind margin.

\section{Distribution}

Red Sea (present study); South Pacific Ocean: New Caledonia, Noumea (Ledoyer 1984); Madagascar, Tulear (Ledoyer 1986). 


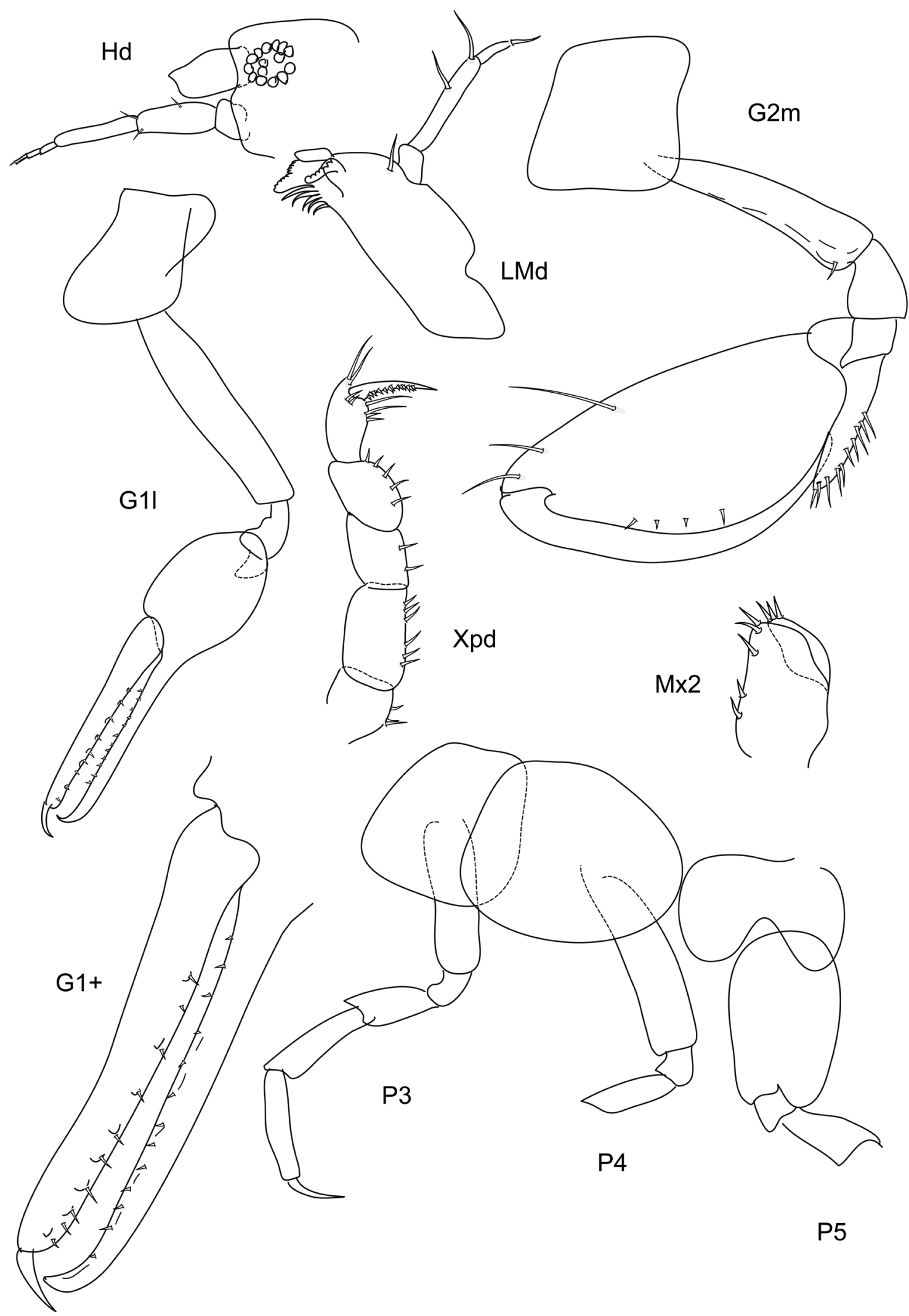

Fig. 12. Leucothoe squalidens Ledoyer, 1984, juv., length $1.6 \mathrm{~mm}$ (MVRCr 7732); 今̊, length $2.0 \mathrm{~mm}$ (MVRCr 7733). 
Genus Paranamixis Schellenberg, 1938

\author{
Paranamixis sommelieri sp. nov. \\ urn:lsid:zoobank.org:act:0A521B78-39B5-4038-AAC6-ABF049671046
}

Figs 13-16

Paranamixis bocki - Ledoyer 1967: 125; 1978: 231, fig. 14. - Ruffo 1969: 13.

?Leucothoides pottsi - Ruffo 1959: 2, pl. 1, figs 1-2. — Ledoyer 1967: 127, fig. 5b; 1979b: 111, fig. 68/2.

?Leucothoides torrida - Ledoyer 1986: 682-84, fig. 263.

non Paranamixis bocki Schellenberg, 1938: 29-30, fig. 14.

\title{
Diagnosis
}

Coxae 2-4 inferior margin thickened and fortified. Gnathopod 2 propodus anterodistal corner with small shallow hump followed by a triangular protrusion of about half width of dactylus, followed by some small triangular knobs along the margin; dactylus curved, reaching about 0.6-0.8 times propodus length, inner margin with two long setae inserted in excavation, after which the dactylus continues abruptly narrowed. Pereopods 5-7 bases widened, not much longer than wide, anterior margin with short setae, posterior margin medially the widest, lower half straight (not concave), upper half rounded. Uropods 1-3 rami unequal.

\section{Etymology}

Our friend Ulrich Schiecke always collected with enormous enthusiasm and idealism, content with a minimum of finances and time on disposition. Numerous species have already been dedicated to him, using the genitive of his first or surname. Thus we reflected on the most striking aspects of his character, and settled on one trait for which he is renowned: he is the best connoisseur of Italian wines we know, and the only person who ever dared to send back not one, but three bottles of already opened wine, much to the surprise of the waiters, who were too stunned to protest, but deeply impressed by his sense of taste. The specific name is used as genitive.

\section{Type material}

\section{Holotype}

SUDAN: ${ }^{\lambda}$ anamorph, 2.8 mm, Port Sudan, stn 168, Dec. 1970, U. Schiecke leg. (ZMB 29753).

\section{Paratype}

SUDAN: $\widehat{~}$ leucomorph, 1.4 mm, N of Port Sudan, Flamingo Bay, stn 203, 1 m, sponge, 29 Nov. 1970, U. Schiecke leg. (ZMB 29754).

\section{Additional material examined}

SUDAN: 2 leucomorphs, N of Port Sudan, Flamingo Bay, stn 203, 1 m, sponge, 29 Nov. 1970, U. Schiecke leg. (slides MVRCr 7723 and MVRCr 7724); 1 anamorph, Port Sudan, Dec. 1970, U. Schiecke leg.; 30 anamorphs, near Port Sudan, Massa Sheik Ibrahim, stn 168, U. Schiecke leg.; 3 anamorphs, 50 leucomorphs, near Port Sudan, Massa Sheik Ibrahim, stn 173, 14 Dec. 1970, U. Schiecke leg.; 40 leucomorphs, Port Sudan, Marsa Arakiyai, stn 180, Dec. 1970, U. Schiecke leg.; 30 leucomorphs, Port Sudan, Flamingo Bay, stn 188, Dec. 1970, U. Schiecke leg.; 1 anamorph, 1 leucomorph, Port Sudan, stn 196, reef and epiphytes, 12 Nov. 1970, U. Schiecke leg.; 6 leucomorphs, Port Sudan, stn 198, Dec. 1970, U. Schiecke leg.; 1 leucomorph, N of Port Sudan, Flamingo Bay, 1 m, sponge, 29 Nov. 1970, U. Schiecke leg.; đo anamorph, 2 mm, near Port Sudan, Massa Sheik Ibrahim, 14 Dec. 1970, U. Schiecke leg. (slide MVRCr 7722). 

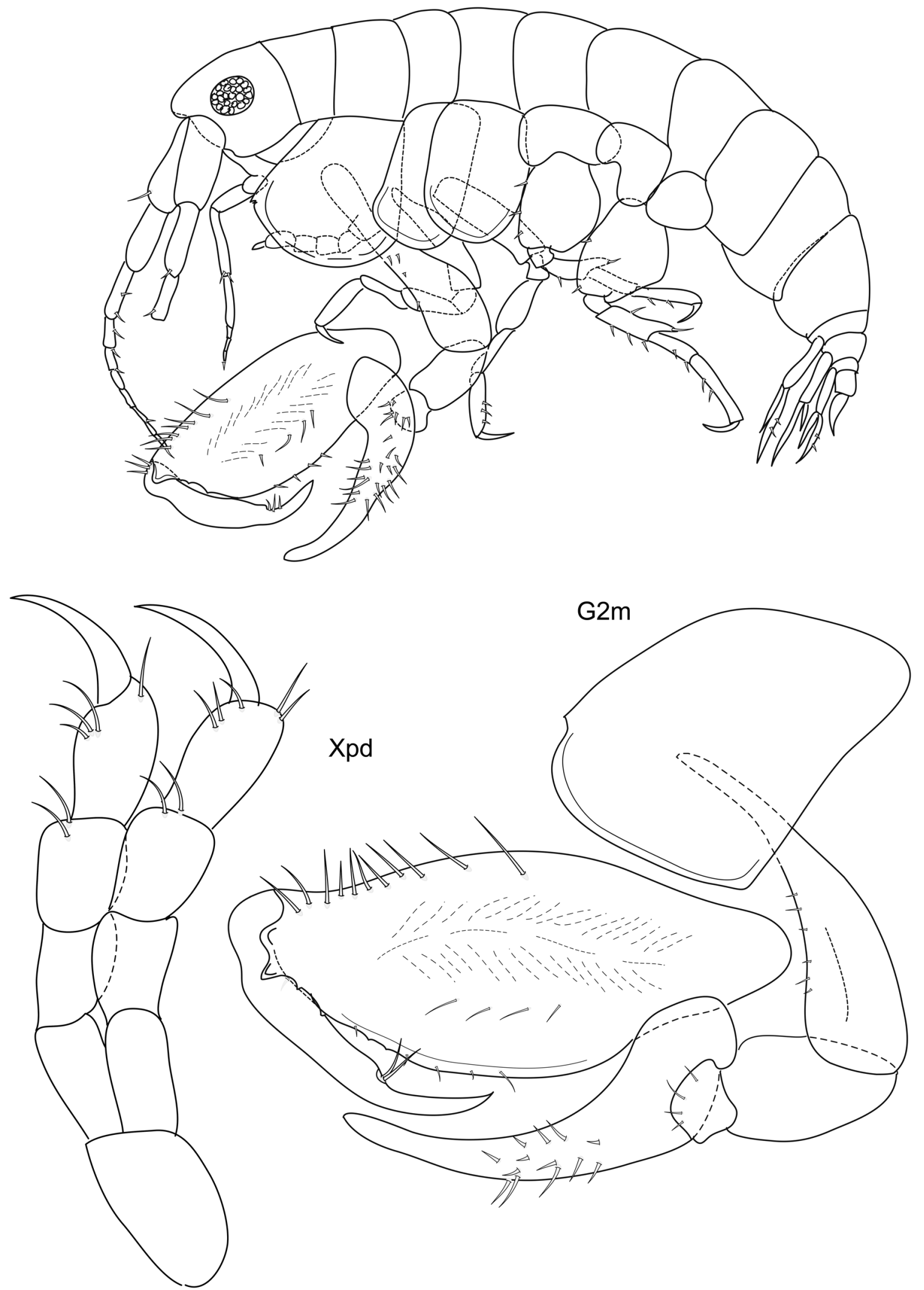

Fig. 13. Paranamixis sommelieri sp. nov., holotype, anamorph ${ }_{0}$, length $2.8 \mathrm{~mm}$ (ZMB 29753). 


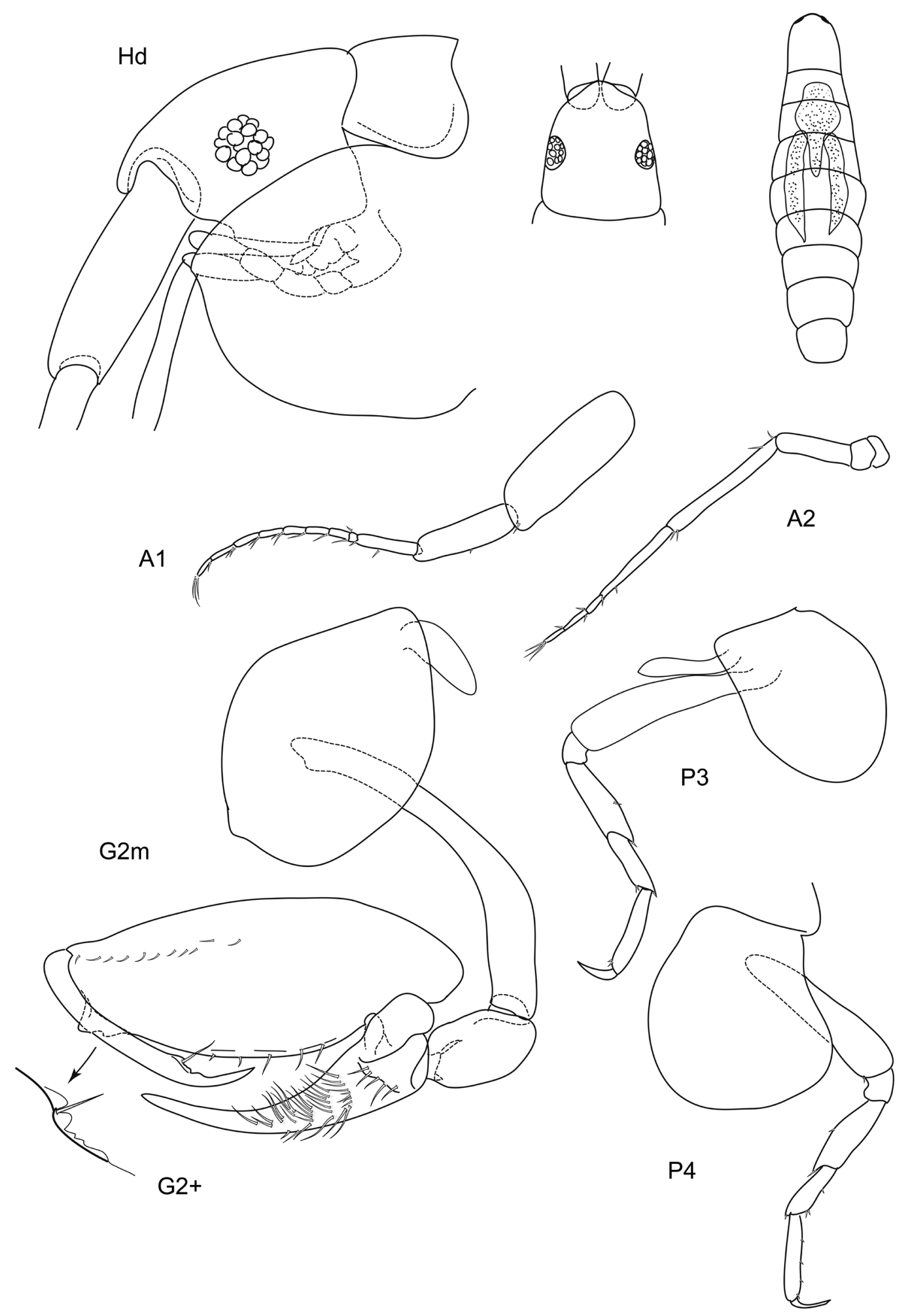

Fig. 14. Paranamixis sommelieri sp. nov., holotype, anamorph $\widehat{\jmath}$, length 2.8 mm (ZMB 29753). 

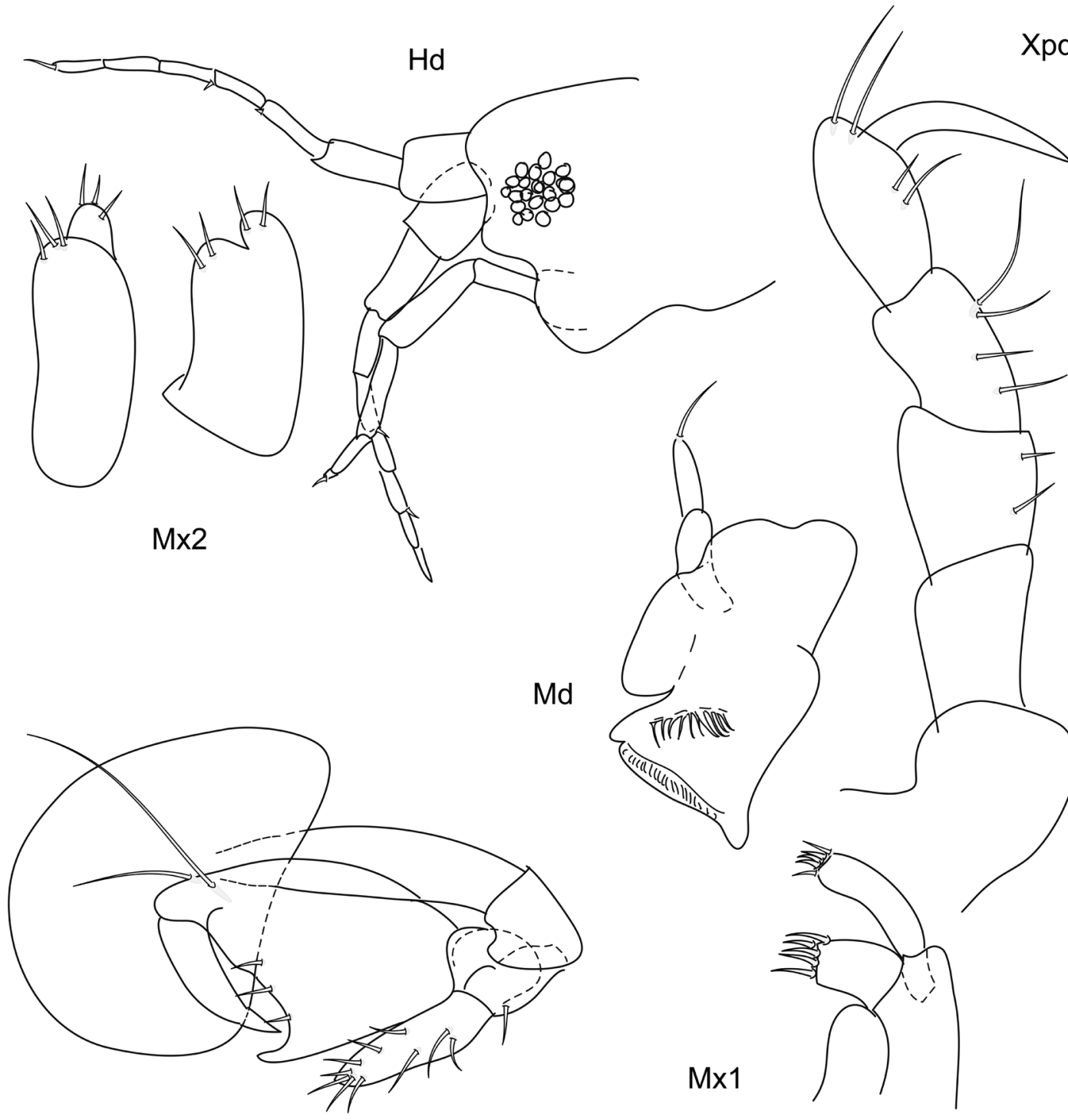

Md

G2I

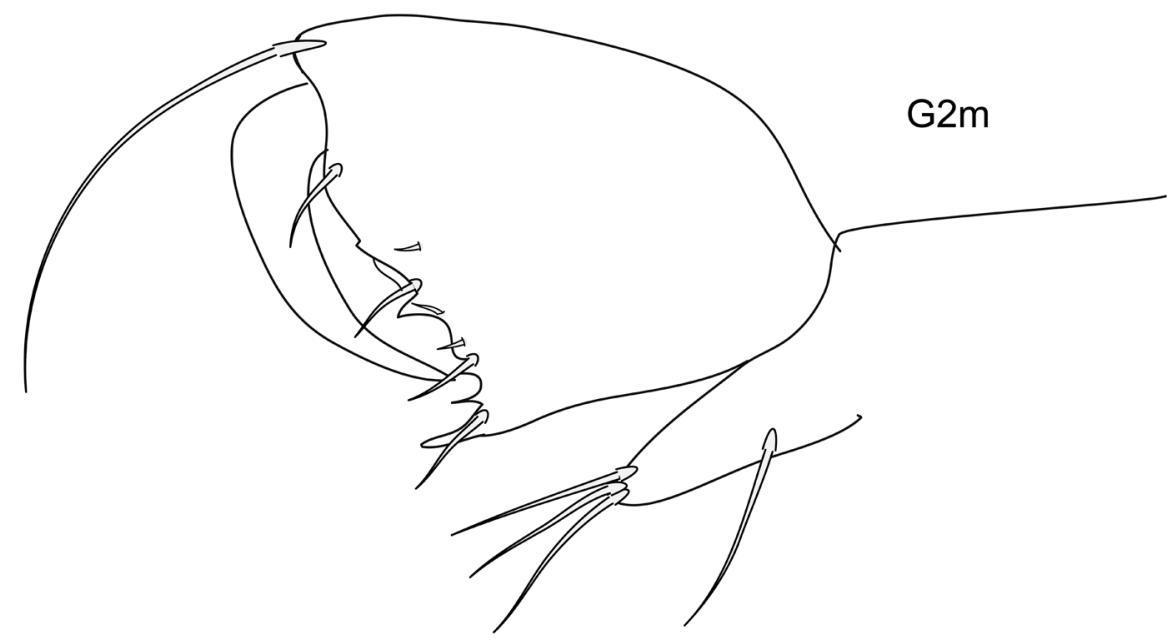

Fig. 15. Paranamixis sommelieri sp. nov., paratype, leucomorph ${ }^{\Uparrow}$, length $1.4 \mathrm{~mm}$ (ZMB 29754). 


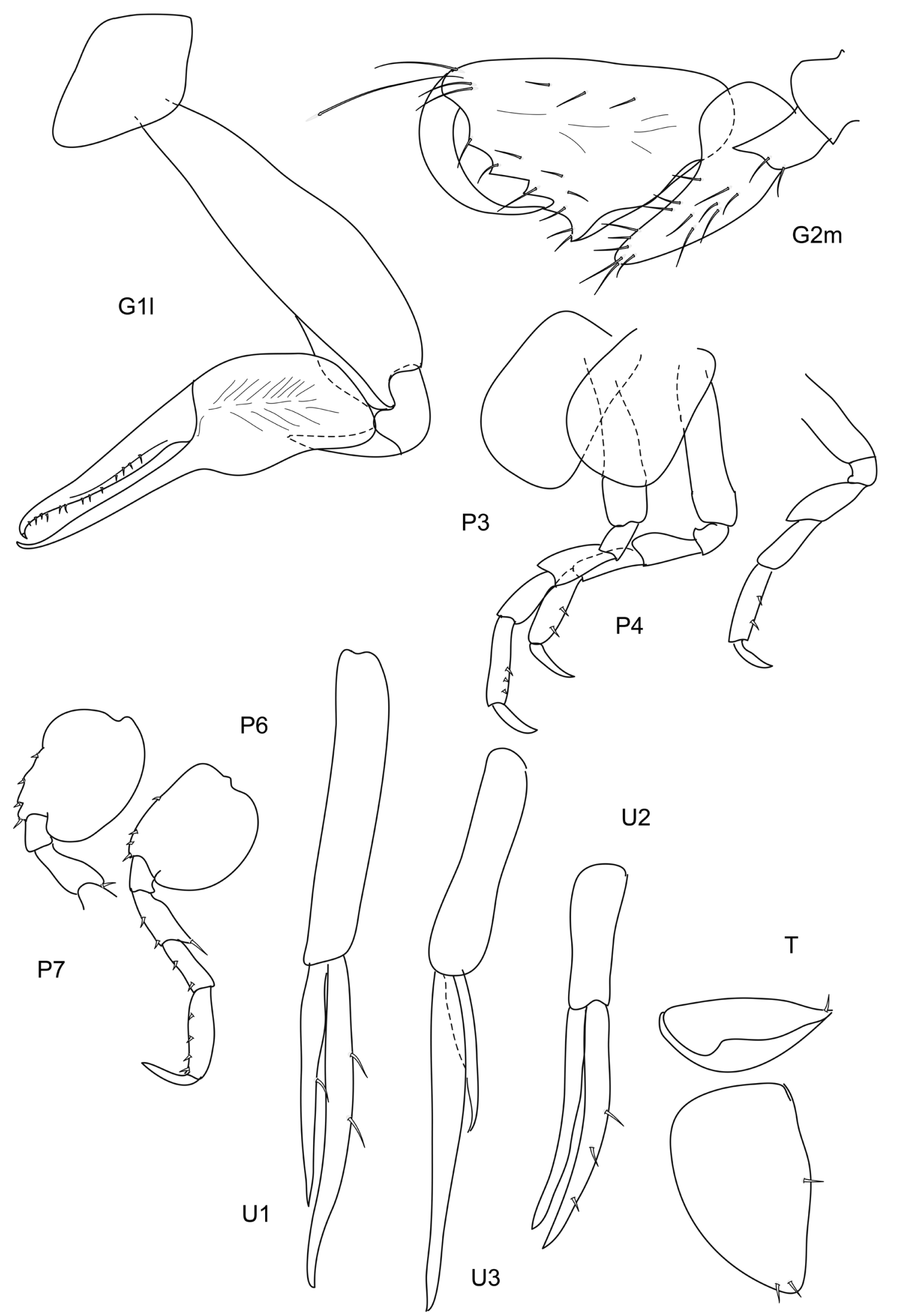

Fig. 16. Paranamixis sommelieri sp. nov., paratype, leucomorph $\stackrel{\jmath}{\text { }}$, length $1.4 \mathrm{~mm}$ (ZMB 29754). 


\section{Description}

\section{Male anamorph}

LENGTH. $2.8-3 \mathrm{~mm}$.

HEAD. Anterior margin rounded, anterodistal margin notched, distal margin rounded; ventral cephalic keel anterior margin transverse, anteroventral margin rounded, ventral margin straight; eyes present with more than 10 ommatidia, round. Antenna 1 length 0.4 times body length, flagellum 8 -articulate, peduncle article 1 width less than 2 times article 2, accessory flagellum absent. Antenna 2 length 0.2 times body length, shorter than antenna 1, flagellum 5-articulate. Mouthparts reduced. Maxilliped inner and outer plates smooth, lacking inner lobes; palp 4-articulate, palp article 4 elongate, slender, strongly recurved.

Pereon. Coxae 1-4 relative widths 1.0: 2.5: 1.5: 1.7. Gnathopod 1 coxa reduced, smooth, bare. Gnathopod 1 absent. Gnathopod 2 coxa longer than broad, much wider than coxa 3, smooth, bare, anterior margin rounded, anterodistal corner with notch, distal margin rounded, posterior margin straight; basis distally expanded, anterior margin with six short setae, posterior margin bare; carpus 0.8 times propodus length, curved, distally tapered, anterior margin smooth; propodus with 1 mediofacial setal row reaching 0.5 times propodus length, 1 submarginal setal row of four setae, posterior margin smooth, palm convex, with one large and several small triangular protrusions and small setae; dactylus curved, reaching 0.5 times propodus length, proximal margin with excavation and two long setae, anterior margin distally tapered, acute. Pereopod 3 coxa length 1.8 times width, anterodistal corner overriding distal face of coxa 2, smooth, anterior margin rounded, distal margin rounded, posterior margin straight. Pereopod 4 coxa smooth, anterior margin rounded, distal margin rounded, posterior margin rounded. Pereopods 5-7 coxae, facial setae absent. Pereopods 5-7 bases width-length ratios 1:1.3, 1:1.2, 1:1.2, posterior margins smooth, bare.

PLEON. Epimera 1-3 bare, epimeron 3 posteroventral corner subquadrate. Uropods 1-3 relative lengths $1.0: 1.0: 0.7$. Uropod 1 peduncle 0.8 times inner ramus length, outer ramus 0.6 times inner ramus length. Uropod 2 peduncle subequal in length with inner ramus, outer ramus 0.4 times inner ramus length. Uropod 3 peduncle subequal in length with inner ramus, outer ramus 0.8 times inner ramus length. Uropods moderately setose.Telson 1.6 times longer than wide, apex blunt.

\section{Female and male leucomorph}

LeNGTH. $1.2-1.8 \mathrm{~mm}$.

HEAD. Anterior margin truncate, anterodistal margin subquadrate, distal margin straight; eyes present with about 20 ommatidia, round. Antenna 1 half of body length, flagellum 5 -articulate, peduncle article 1 robust, articles 2 and 3 narrower, accessory flagellum absent. Antenna 2 length 0.3 times body length, subequal to antenna 1 length (but geniculate), flagellum 3-articulate. Mandibular palp 2-articulate, article 2 with one distal seta, mandibles with 10 raker spines. Maxilla 1 palp 1-articulate, with 4 distal slender setae; outer plate with 5 distal robust setae. Maxilla 2 inner and outer plates each with 2-3 distal slender setae. Maxilliped outer plate vanishing; palp 4-articulate, article 4 subequal in length with article 3 , distally acute.

Pereon. Coxae 1-4 relative widths 1.0:1.5:0.9:0.9. Gnathopod 1 coxa smooth, trapezium-shaped, anterodistal margin produced, distal margin straight; basis long and smooth, distally moderately expanded, anterior and posterior margins bare; ischium bare; carpus straight, distally thin, length 14 times width, proximal margin smooth; propodus strongly narrowing distally, palm smooth with many marginal setae; dactylus minute. Gnathopod 2 coxa longer than broad, wider than coxa 3, smooth, anterior margin regularly rounded, anterodistally rounded, distal margin nearly straight, posterior margin straight or somewhat concave; basis not expanded, anterior margin with few short setae, posterior margin bare; 
ischium bare; carpus 0.4 times propodus length, straight, distally tapered, margins smooth but setose; propodus with 1 mediofacial setal row, with row of submarginal setae, posterior margin smooth, posterior margin triangular, palm with long acute tooth on rectangular palmar corner, with triangular tubercles; dactylus strongly curved, distally acute, margins smooth, bare. Pereopod 3 coxa length 1.5 times width, anterodistal corner overriding distal face of coxa 2, smooth, anterior margin rounded, distal margin slightly rounded, posterior margin straight. Pereopod 4 coxa smooth, similar to coxa 3 , anterior margin rounded, distal margin rounded, posterior margin straight. Pereopods 5-7 bases width-length ratios $1: 1.4,1: 1.3,1: 1.2$, posterior margins rounded, smooth, bare.

PLEON. Epimera 1-3 bare, epimeron 3 posteroventral corner subrectangular. Uropods $1-3$ relative lengths $1.0: 0.8: 0.6$. Uropod 1 peduncle subequal in length with inner ramus, outer ramus 0.7 times inner ramus length. Uropod 2 peduncle 0.8 times inner ramus length, outer ramus 0.5 times inner ramus length. Uropod 3 peduncle shorter than subequal rami. Uropods 1-3 rami with robust setae. Telson 1.6 times longer than wide, with 2 distal and one marginal setae, apex bluntly rounded.

\section{Remarks}

The only species of Paranamixis cited until now from the Red Sea is P. bocki Schellenberg, 1938 (Ruffo 1969). Ruffo (loc. cit.) discussed two specimens only verbally and ascribed them to the material published by Ledoyer (1967). Schellenberg (1938) illustrated from his single specimen of $3 \mathrm{~mm}$ (from the Gilbert Islands, Central Pacific) an elliptical coxa 2 with a sharp protruding rectangular tooth, while Ledoyer's drawings (no length of the specimen indicated) show a subquadrate coxa 2 with a small incision on the anterior margin. Coxa 2 as figured by Ledoyer (1967: fig. 5) is malformed in the upperleft corner of the sketch of the head; it also seems clear that the rostrum is not as acute as it is drawn. Ledoyer (1978) compared the material from Tuléar (Madagascar) published in 1967 with his specimens from Mauritius and thought that both belonged to the same species, but the attribution to P. bocki is cited with a question mark. Thomas (1997) repeated this doubt: he cited the original description of P. bocki by Schellenberg but did not attribute the material of Ledoyer $(1967,1978)$ to this species. There is also a quite different gnathopod 2 propodus (in Schellenberg's illustration without the characteristic triangular protrusion on propodus anterodistal corner), but this could be due to allometry, as only small and shallow humps instead of strikingly prominent ones were also observed in our material sometimes. However, the difference in the coxa 2 shape is too strong to be changed with age.

Thomas (1997) described P. clarkae from the Seychelles, and illustrations of his material (length 2.7$3.15 \mathrm{~mm}$ ) bear quite a good resemblance to material studied herewithin. The major difference is the posterior margin of pereopod bases 5 and 6 , which is clearly excavated in the inferior half vs straight in our material. Thomas (1997) compared his material with P. excavatus Ledoyer, 1978 from Mauritius, but here we find clear differences: coxa 2 again shows the blunt corner followed by a short concave margin similar to $P$. bocki, and uropod 3 has subequal rami. Paranamixis madagascariensis Ledoyer, 1982 has quite small eyes and a regularly rounded coxa 2, similar to P. indicus Sivaprakasam, 1968 in the illustration of the holotype, where gnathopod 2 dactylus also has a deep excavation on the proximoinferior half; figures of males from station 4 fit well to our material, showing the blunt corner on coxa 2 antero-distal margin and no excavation on the dactylus.

\section{Ecology}

This species was collected among sponges.

\section{Distribution}

Red Sea (present study). 


\section{Discussion}

Cryptic species complexes within Leucothoidae are becoming apparent around the world (Thomas \& Klebba 2006, 2007; Krapp-Schickel \& De Broyer 2014; Thomas 2015). Examination of many reports pertaining to one species (i.e., Leucothoe spinicarpa Abildgaard, 1789) often reveal several different, yet morphologically similar species. Even without cryptic species complexes, invertebrates from the Red Sea are poorly known, and the need for an expansion of research into coral reefs of the Red Sea has been documented (Berumen et al. 2013).

This study increases the number of leucothoid species reported from the Red Sea from six to 14 (see * signs in Table 1 for the six species already known). It widens the known range of L. acutilobata, L. predenticulata and L. squalidens from the Western Indian Ocean (and the South Pacific) to include the Red Sea (see + signs in Table 1), and describes three new species of Leucothoe as well as one new species of Paranamixis from the Red Sea.

The long-overdue re-description of Leucothoe acanthopus Schellenberg, 1928 provides clarification of its morphology. It is now apparent that the many reports of $L$. bannwarthi actually represent a species complex with multiple similar species, one of which is described herein. Further examination of specimens reported from Micronesia (J.L. Barnard 1965; Myers 2013), the Philippines (Olerød 1970), the wider tropical Pacific (Schellenberg 1938; Myers 1985), Madagascar (Ledoyer 1967, 1972, 1978, 1979, 1986), and the Indo-Pacific (Ortiz \& Lalana 1997) is necessary to determine how many species this complex represents and which report can be attributed to which species.

As shown in Table 1, Ledoyer $(1967,1972,1978,1979,1986)$ cites six species described from distant localities. It will be necessary to check and most probably redescribe the following five species collected by him: Leucothoe euryonyx (type locality W-Mediterranean), L. hyhelia (type loc. Marshall Islands), L. lihue (type loc. Hawaii), L. madrasana (type loc. India), L. micronesiae (type loc. Caroline Isl.). The sixth, L. richiardii (type loc. central Mediterranean), could already be ascribed to $L$. safiae Lyons \& Myers here in this paper.

It is well known that Leucothoe species are living with or within other animals, and they are certainly neither cosmopolitan (as long thought for L. spinicarpa (Abildgaard, 1789)), nor widespread. In most cases, different species have developed with rather small morphological variations or even as cryptic species, which can only be detected by molecular studies.

\section{Acknowledgements}

This research was partially supported by award No. 1389-CRG1 and baseline funding from the King Abdullah University of Science and Technology (KAUST) to Michael L. Berumen. The following people are thanked for logistical support: M.L. Berumen, J.D. Reimer, L. Chen, J. Di Battista, A. Gusti, A. Macauley, C. Nelson, M. Priest, and T. Sinclair-Taylor of KAUST, and the crew of the MY 'Dream Master'. James D. Reimer (collector) was additionally supported in part by the International Research Hub Project for Climate Change and Coral Reef/Island Dynamics at the University of Ryukyus. Thanks are also due to Wayne Price for providing lab space and microscope use at The University of Tampa.

\section{References}

Abildgaard P.C. 1789. Zoologia Danica seu animalium Daniae et norvegiae rariorum ac minus notorun Descriptiones et Historia. Copenhagen, N. Möller. 
Berumen M.L., Hoey A.S., Bass W.H., Bouwmeester J., Catania D., Cochran J.E.M., Khalil M.T., Miyake S., Mughal M.R., Spaet J.L.Y. \& Saenz-Agudelo P. 2013. The status of coral reef ecology research in the Red Sea. Coral Reefs 32: 737-748. https://doi.org/10.1007/s00338-013-1055-8

Barnard J.L. 1965. Marine Amphipoda of Atolls in Micronesia. Proceedings of the United States National Museum 117 (3516): 459-552. https://doi.org/10.5479/si.00963801.117-3516.459

Barnard K.H. 1916. Contributions to the Crustacean Fauna of South Africa. Annals of the South African Museum 15 (3): 105-302.

Barnard K.H. 1937. Amphipoda. John Murray Exp. 1933-34. British Museum (Natural History) Scientific Reports 4 (6): 131-209.

Bussarawich S., Nateewathana A. \& Hylleber J. 1984. Distribution of marine benthic amphipods off Phuket Island, with emphasis on tin mining and a model of species-individual relationships. Phuket Marine Biology Center Research Bulletin 32: 1-21.

Coleman O. 2003. "Digital inking": how to make perfect line drawings on computers. Organisms, Diversity \& Evolution 3 (4): 303-304. https://doi.org/10.1078/1439-6092-00081

Griffiths C.L. 1974a. The Amphipoda of southern Africa. Part 3. The Gammaridea and Caprellidea of Natal. Annals of the South African Museum 62 (7): 209-264.

Griffiths C.L. 1974b. The Amphipoda of southern Africa. Part 4. The Gammaridea and Caprellidea of the Cape Province east of Cape Agulhas. Annals of the South African Museum 65 (9): 251-336.

Griffiths C.L. 1975. The Amphipoda of southern Africa. Part 5. The Gammaridea and Caprellidea of the Cape Province west of Cape Agulhas. Annals of the South African Museum 67 (5): 91-181.

Kossmann R. 1880. Malacostraca. Zoologische Ergebnisse im Auftrage der königlichen Academie für Wissenschaften in Berlin. Reise an die Küstengebiete des Rothen Meeres 2: 67-140.

Krapp-Schickel T. \& De Broyer C. 2014. Revision of Leucothoe (Amphipoda, Crustacea) from the Southern Ocean: a cosmopolitan concept is vanishing. European Journal of Taxonomy 80: 1-55. https:// doi.org/10.5852/ejt.2014.80

Leach W.F. 1814. Crustaceology. In: Brewster D. (ed.) The Edinburgh Encyclopedia: 383-437. Blackwood, Edinburgh.

Ledoyer M. 1967. Amphipodes Gammariens des Herbiers de Phanérogames marines de la région de Tuléar (Rep. Malgache). Etude systématique et écologique. Annales de l'Université de Madagascar 5: 121-170.

Ledoyer M. 1972. Amphipodes Gammariens vivant dans les alvéoles des constructions organogènes récifales intertidales de la région de Tuléar (Madagascar). Etude systématique et écologique. Tethys Supplement 3: 165-286.

Ledoyer M. 1978. Contribution à l'étude des amphipodes gammariens profonds de Madagascar (Crustacea). Tethys 8 (4): 365-382.

Ledoyer M. 1979. Les Gammariens de la pente externe du grand récif de Tuléar (Madagascar). Memorie del Museo Civico di Storia Naturale, Verona, Series 2, Sezione Science della Vita 2: 1-150.

Ledoyer M. 1984. Les Gammariens (Crustacea, Amphipoda) des herbiers phanerogames marines de Nouvelle Calédonie (région de Nouméa). Mémoires du Muséum national d'Histoire naturelle série A Zoologie 129: 1-113.

Ledoyer M. 1986. Crustacés amphipodes gammariens. Faune de Madagascar 59 (2): 599-1112. 
Lowry J.K. \& Stoddart H.E. 2003. Crustacea: Malacostraca: Peracarida: Amphipoda, Cumacea, Mysidacea. In: Beesley P.L. \& Houston W.W.K. (eds) Zoological Catalogue of Australia Volume 19.2B: 1-531. CSIRO Publishing, Melbourne.

Lyons J. \& Myers A.A. 1991. Amphipoda Gammaridea from coral rubble in the Gulf of Aqaba, Red Sea: families Dexaminidae, Eusiridae, Isaeidae, Ischyroceridae, Leucothoidae, Liljeborgiidae and Lysianassidae. Journal of Natural History 25: 597-621. https://doi.org/10.1080/00222939100770381

Minelli A. 1993. Biological Systematics. Chapman \& Hall, London/Glasgow/New York/Tokyo/ Melbourne/Madras.

Monod T. 1937. Missions A. Gruvel dans le Canal de Suez: Crustacés I. Mémoires de l'institut d'Egypte 34: $1-19$.

Montagu G. 1804. Description of several marine animals found on the South coast of Devonshire. Transactions of the Linnean Society of London 7: 61-85. https://doi.org/10.1111/j.1096-3642.1804. $\underline{\mathrm{tb} 00282 . \mathrm{x}}$

Myers A.A. 1985. Shallow-water, coral reef and mangrove Amphipoda (Gammaridea) of Fiji. Records of the Australian Museum, Supplement 5: 1-143. https://doi.org/10.3853/j.0812-7387.5.1985.99

Myers A.A. 1986. Amphipoda from the South Pacific: Tonga. Records of the Australian Museum 38: 271-289. https://doi.org/10.3853/j.0067-1975.38.1986.183

Myers A.A. 2013. Amphipoda (Crustacea) from Palau, Micronesia: Families Dexaminidae, Esuiridae, Hyalidae, Ischyroceridae, Leucothoidae, and Lysianassidae. Zootaxa 3731 (3): 301-323. https://doi. org/10.11646/zootaxa.3731.3.1

Olerød R. 1970. Littoral gammaridean Amphipoda from Mindoro, the Phillipines. Zoologischer Anzeiger 184: 359-396.

Ortiz M. \& Lalana R. 1997. Amphipoda. Travaux du Musée d'Histoire naturelle "Grigore Antipa" 38: 29-113.

Rudwick M.J.S. 1951. Notes on some Crustacea (Amphipoda) from Aden. Annals and Magazine of Natural History Series 12 4: 149-156.

Ruffo S. 1959. Contributo alla conoscenza degli Anfipodi del Mar Rosso (materiali raccolti a Ghardaqa e nel Golgo di Aqaba). Sea Fisheries Research Station Haifa, Bulletin 20: 1-26.

Ruffo S. 1969. Study sui Crostacei Anfipodi LXXVII. Terzo contributo alla conocenza degli Anfipodi del Mar Rosso. Memorie del Museo Civico di Storia Naturale di Verona 17: 1-77.

Savigny J.C. 1816. Mémoires sur les Animaux sans vertèbres. Première partie. Description et classification des animaux invertébrés et articulés, connus sous les noms de Crustacés, d'Insectes, d'Annélides, etc. Chez Deterville, Paris.

Schellenberg A. 1928. Report on the Amphipoda. Zool. Res. Cambridge Exp. to the Suez Canal, 1924, XXXV. Transactions of the Zoological Society of London 22: 633-692. https://doi. org/10.1111/j.1096-3642.1928.tb00209.x

Schellenberg A. 1938. Litorale Amphipoden des tropischen Pazifiks. Kungliga Svenska Vetenskapsakademiens Handlingar III 16 (6): 1-105.

Shoemaker C. 1933. Amphipoda from Florida and the West Indies. American Museum Novitates 598.

Sivaprakasam T.E. 1968. Amphipoda from the east coast of India. Part 1. Gammaridea. Journal of the Marine Biological Association of India 8 (1): 82-122. 
Sowinsky W. 1897. Les Crustacés supérieures (Malacostraca) du Bosphore. I. Amphipoda et Isopoda. Mémoires de la Société des Naturalistes de Kiev 15: 1-72.

Sowinsky W. 1898. Vuisshiya rakoobraznuiya (Malacostraca) Bosfora, po materialam sobrannuim d-rom A.A. Ostroumovuim v 1892 y 93 ghgh. I. Amphipoda y Isopoda. Mémoires de la Société des Naturalistes de Kiew 15 (2): 490-518.

Stebbing T.R.R. 1897. Amphipoda from the Copenhagen Museum and other sources. Part I. Transactions of the Linnean Society of London (2 Zoology) 7: 25-45.

Stebbing T.R.R. 1899. Amphipoda from the Copenhagen Museum and other sources. Part II. Transactions of the Linnean Society of London (2 Zoology) 7: 395-433.

Stebbing T.R.R. 1906. Amphipoda, I. Gammaridea. Das Tierreich 21: 1-806.

Thomas J.D. 1997. Systematics, Ecology and Phylogeny of the Anamixidae (Crustacea: Amphipoda). Records of the Australian Museum 49: 35-98. https://doi.org/10.3853/j.0067-1975.49.1997.298

Thomas J.D. 2015. Leucothoe eltoni sp. n., a new species of commensal leucothoid amphipod from coral reefs in Raja Ampat, Indonesia (Crustacea, Amphipoda). Zookeys 518: 51-66. https://doi.org/10.3897/ zookeys. 518.9340

Thomas J.D. \& Klebba K.N. 2006. Studies of commensal leucothoid amphipods, two new spongeinhabiting species from south Florida and the western Caribbean. Journal of Crustacean Biology 26: 13-22. https://doi.org/10.1651/C-2624.1

Thomas J.D. \& Klebba K.N. 2007. New species and host associations of commensal leuocthoid amphipods from coral reefs in Florida and Belize (Crustacea, Amphipoda). Zootaxa 1494: 1-44.

Walker A.O. 1904. Report on the Amphipoda collected by Professor Herdman at Ceylon in 1902. Report to the Gulf of Ceylon on the Pearl Oyster Fisheries of the Gulf of Manaar, Supplementary Report: 229-300. The Royal Society, London.

Walker A.O. 1905. Marine crustaceans. XVI. Amphipoda. Fauna and Geography of the Maldive and Laccadive Archipelagos 2 (Supplement 1): 923-932.

Walker A.O. 1909. Amphipoda Gammaridea from the Indian Ocean, British East Africa and the Red Sea. Transactions of the Linnean Society of London, Zoology (2) 12: 323-344.

White K.N. \& Reimer J.D. 2012. DNA phylogeny of Ryukyus Leucothoidae (Crustacea: Amphipoda). Contributions to Zoology 81 (3): 159-165.

Manuscript received: 26 June 2016

Manuscript accepted: 2 September 2016

Published on: 31 May 2017

Topic editor: Gavin Broad

Desk editor: Chloe Chester

Printed versions of all papers are also deposited in the libraries of the institutes that are members of the EJT consortium: Muséum national d'Histoire naturelle, Paris, France; Botanic Garden Meise, Belgium; Royal Museum for Central Africa, Tervuren, Belgium; Natural History Museum, London, United Kingdom; Royal Belgian Institute of Natural Sciences, Brussels, Belgium; Natural History Museum of Denmark, Copenhagen, Denmark; Naturalis Biodiversity Center, Leiden, the Netherlands; Museo Nacional de Ciencias Naturales-CSIC, Madrid, Spain; Real Jardín Botánico de Madrid CSIC, Spain. 